Review

\title{
Non-Coding RNAs as Biomarkers of Tumor Progression and Metastatic Spread in Epithelial Ovarian Cancer
}

\author{
Karolina Seborova ${ }^{1,2}$, Radka Vaclavikova ${ }^{1,2,+}$, Lukas Rob ${ }^{3}$, Pavel Soucek ${ }^{1,2}$ (I) and Pavel Vodicka ${ }^{2,4,5, *, \dagger}$ \\ 1 Toxicogenomics Unit, National Institute of Public Health, 10042 Prague, Czech Republic; \\ karolina.seborova@szu.cz (K.S.); radka.vaclavikova@szu.cz (R.V.); pavel.soucek@szu.cz (P.S.) \\ 2 Biomedical Center, Faculty of Medicine in Pilsen, Charles University, 32300 Pilsen, Czech Republic \\ 3 Department of Gynecology and Obstetrics, Third Faculty of Medicine and Faculty Hospital Kralovske \\ Vinohrady, Charles University, 10042 Prague, Czech Republic; lukas.rob@fnkv.cz \\ 4 Institute of Experimental Medicine, CAS, 14220 Prague, Czech Republic \\ 5 Institute of Biology and Medical Genetics, First Faculty of Medicine, Charles University, \\ 12000 Prague, Czech Republic \\ * Correspondence: pavel.vodicka@iem.cas.cz \\ + These authors share senior authorship.
}

check for updates

Citation: Seborova, K.; Vaclavikova, R.; Rob, L.; Soucek, P.; Vodicka, P. Non-Coding RNAs as Biomarkers of Tumor Progression and Metastatic Spread in Epithelial Ovarian Cancer. Cancers 2021, 13, 1839. https:// doi.org/10.3390/cancers13081839

Academic Editor: Patrizia Limonta

Received: 15 March 2021

Accepted: 8 April 2021

Published: 12 April 2021

Publisher's Note: MDPI stays neutral with regard to jurisdictional claims in published maps and institutional affiliations.

Copyright: (C) 2021 by the authors Licensee MDPI, Basel, Switzerland. This article is an open access article distributed under the terms and conditions of the Creative Commons Attribution (CC BY) license (https:// creativecommons.org/licenses/by/ $4.0 /)$.
Simple Summary: Despite advances in cancer research in recent years, efficient predictive biomarkers of tumor progression and metastatic spread for ovarian cancer are still missing. Therefore, we critically address recent findings in the field of non-coding RNAs (microRNAs and long non-coding RNAs) and DNA methylation in ovarian cancer patients as promising novel biomarkers of ovarian cancer progression.

Abstract: Ovarian cancer is one of the most common causes of death among gynecological malignancies. Molecular changes occurring in the primary tumor lead to metastatic spread into the peritoneum and the formation of distant metastases. Identification of these changes helps to reveal the nature of metastases development and decipher early biomarkers of prognosis and disease progression. Comparing differences in gene expression profiles between primary tumors and metastases, together with disclosing their epigenetic regulation, provides interesting associations with progression and metastasizing. Regulatory elements from the non-coding RNA families such as microRNAs and long non-coding RNAs seem to participate in these processes and represent potential molecular biomarkers of patient prognosis. Progress in therapy individualization and its proper targeting also rely upon a better understanding of interactions among the above-listed factors. This review aims to summarize currently available findings of microRNAs and long non-coding RNAs linked with tumor progression and metastatic process in ovarian cancer. These biomolecules provide promising tools for monitoring the patient's response to treatment, and further they serve as potential therapeutic targets of this deadly disease.

Keywords: ovarian cancer; progression; metastasis; ncRNA; miRNA; lncRNA; biomarkers; epigenetics

\section{Introduction}

Ovarian cancer (OC) is a complex heterogeneous malignant disease and the second cause of female cancer deaths attributed to gynecological tumors. According to GLOBOCAN 2018, OC is the eighth most common cancer (both in incidence and mortality) worldwide among women [1]. Tumors of epithelial origin represent the most frequently diagnosed OC type (90\%) and comprise type I (endometrioid, mucinous, clear cell, and low-grade serous ovarian carcinomas) and type II that includes carcinosarcomas, undifferentiated carcinomas, and high-grade serous ovarian carcinomas (HGSCs), accounting for $70 \%$ of OC cases [2,3]. The disease is usually diagnosed at an advanced stage (FIGO III and IV) when the 5 -year survival rate is approximately $20-45 \%$, while it is $40-70 \%$ for stage I. 
While localized disease exhibits a 5-year survival rate of $80 \%$, the advanced disease has a 5 -year survival rate of only $30 \%[4,5]$.

Most of the OC patients undergo chemotherapy combining platinum derivatives (carboplatin and cisplatin) and taxanes (paclitaxel and docetaxel) [6]. New therapeutic approaches have been introduced to the therapy of OC recently, e.g., poly(ADP-ribose) polymerase inhibitors (PARPi), such as olaparib, or antiangiogenic agents such as bevacizumab or pazopanib $[7,8]$.

Nowadays, among the main diagnostic tools, we count physical examination, serum level of oncomarker CA125 (or HE4 in some cases), computed tomography, and transvaginal ultrasonography $[9,10]$. The lack of reliable biomarkers for early OC detection enables diagnosis only due to non-specific symptoms when the disease is already in progress. Late diagnosis at advanced stages of OC is related to chemotherapy resistance and the development of metastases. Progression of OC and metastatic spread involves the dissemination of tumor cells from primary tumors.

Molecular characteristics of OC subtypes, based on genetic variability, have been described a few years ago. Rojas et al. summarized specific gene mutation profiles for Type I OC (mutations in the MAPK pathway-KRAS, BRAF, PTEN, CTNNB1, etc.) and Type II OC (TP53, BRCA1, BRCA2, KIT, and EGFR) that could represent novel therapeutic targets or biomarkers of therapeutic efficacy [3]. Clinicopathological and molecular characteristics of Type I and Type II OC subtypes correspond with prognosis and response to treatment [11]. As recently overviewed, DNA repair machinery also plays an important role in the OC development risk, prognosis, and therapeutic outcome [12].

Although the importance of genetic variation and mRNA expression profiles was already well characterized [3,10], the roles of regulatory elements as non-coding RNAs (ncRNAs) and epigenetic regulation (including DNA methylation and histone or chromatin post-translational modifications) became recently broadly studied thanks to the advent of new experimental techniques. Over $98 \%$ of the human transcriptome lacks protein-coding capacity. Despite this fact, the non-protein-coding transcriptome has an important role in cellular processes, including chromatin remodeling, transcription, post-transcriptional modifications, and signal transduction [13]. Non-coding RNAs, referred to as ncRNAs, are a part of networks influencing cell proliferation, invasion, migration, EMT, angiogenesis, DNA repair, cell signaling, and, finally, diverse physiological programs with developmental and oncological contexts. ncRNAs (miRNAs, circular RNAs-circRNAs, siRNAs, piRNAs, and $\operatorname{lncRNAs}$ ) regulate the expression of protein-coding genes or interact with other species of ncRNA and regulate their stability. ncRNA may interact with other non-coding elements through mechanisms, including sequestration. Figure 1 represents a simplified scheme of general ncRNAs functional properties.

In this review, we focus our attention on regulatory elements belonging to ncRNAs (particularly microRNA (miRNAs) and long non-coding RNAs (lncRNAs)) and their associations with the progression and development of OC metastases investigated using both in vitro models and patient tumor tissue specimens. 


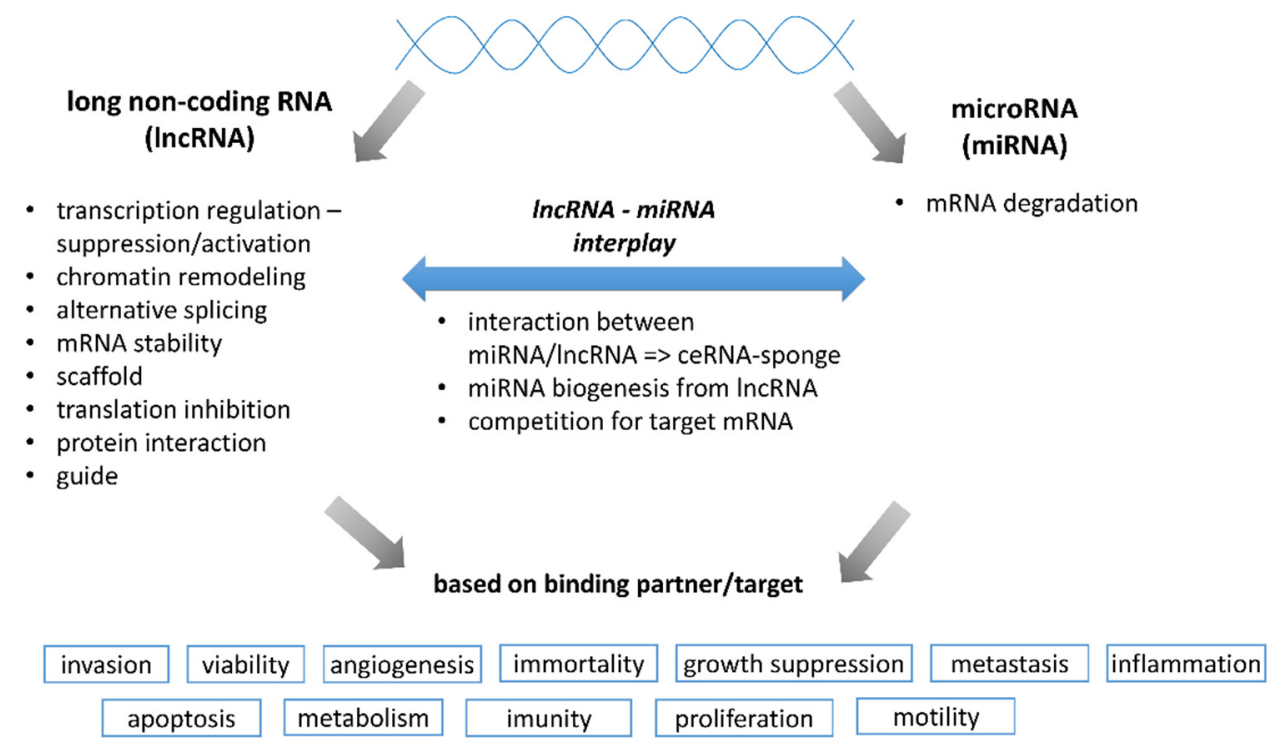

Figure 1. Simplified overview of lncRNA and miRNA functional properties. This figure shows possible interacting molecular determinants for lncRNA and miRNA as well as a wide range of cellular processes influenced by lncRNA/miRNA interactions with target binding partners.

\section{Progression of Ovarian Carcinoma and Development of Metastases}

The metastatic process consists of the following steps: (i) separation of tumor cells from the primary tumor site; (ii) escape of tumor cells to the circulatory system (blood, lymph); (iii) adhesion of tumor cells to the endothelium of a vessel wall, followed by their evasion from the circulatory system and formation of the new tumor loci; and (iv) proliferation and tumor growth of metastatic cells in a new location. OC metastases disseminate throughout the body via peritoneal, hematogenous, and lymphatic routes. Most metastatic lesions affect the peritoneum/omentum or abdominal organs by the most prevalent peritoneal route. Tumor cells also often infiltrate pelvic lymphatic nodes with subsequent metastatic spread to the liver or lungs (Figure 2). Essential steps of the metastatic process have been in detail reviewed in several reviews, see, for example, in [14-16]. In a study by Deng et al. on 1481 OC patients, the liver was identified as the most common distant site of metastases development, followed by lymph nodes, lungs, bones, and brain [17]. Molecular determinants of individual steps in the metastatic development and spread are linked with the following genes. First step-metastasis initiation of transcoelomic route is defined by loss of cell adhesion, characterized by key genes (CDH1, CDH2, and UPAR) [18,19], epithelial-mesenchymal transition (EMT) (ZEB1, ZEB2, SNAI1, and SNAI2) [20], migration (UPA) [21], and spheroid formation (HGF) [22]. The next step is metastasis progression characterized by dissemination in the peritoneal cavity (VEGFA, MMP2, MMP9, CXCRL4, CXCL12, and CD44) [23-25], resistance to anoikis (RAB25) [26], and evading apoptosis/immunity. The last step-metastasis spread, starts with attachment to the peritoneal surface (MMP2, MMP9, MMP14, CDH1, and LPA) [27-29], formation of metastases (UPAR and SPINK13) [30], and subsequent invasion (DNMT1, MAPK1, MAPK3, and ETS1) [31,32], and angiogenesis (VEGFA, IL1, and IL6) $[33,34]$. The hematogenous route of metastases development is more prevalent than formerly estimated [35]. 


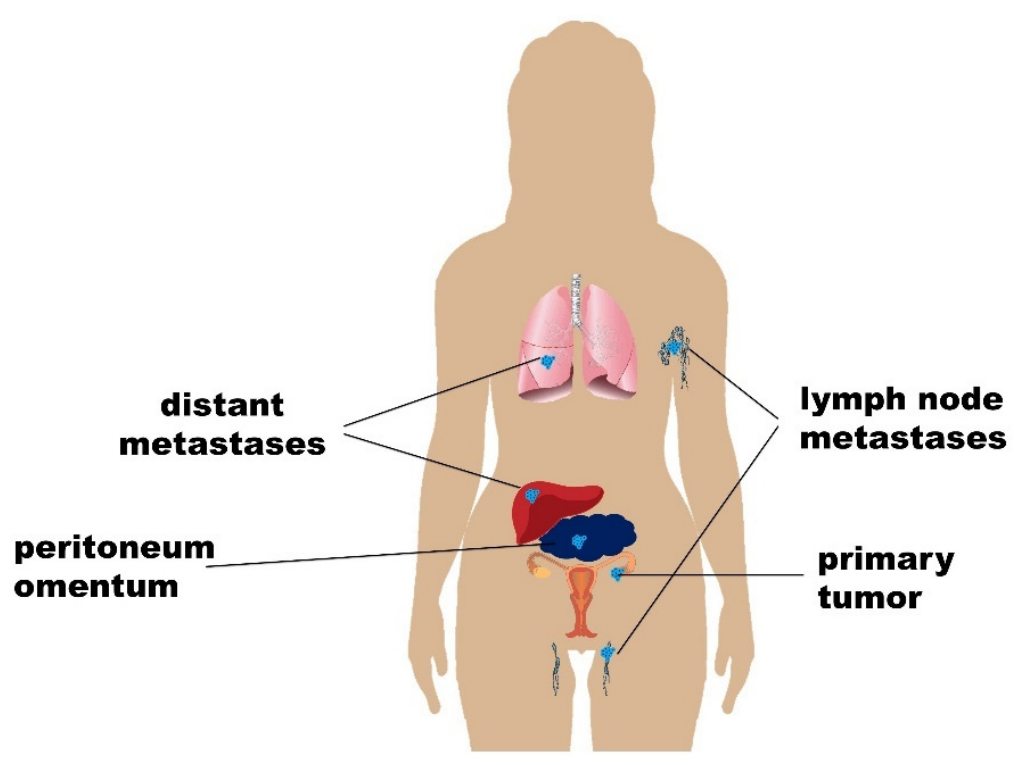

Figure 2. Metastatic routes of ovarian cancer (OC) metastasis. This scheme shows different metastatic scenarios in OC. The transcoelomic/peritoneal route is the main route in OC metastases development, especially into the peritoneum/omentum. During the subsequent progression, metastases in distant lymph nodes and organs (lungs or liver) are developed.

Adherent epithelial cells are transformed into invasive mesenchymal cells during EMT, which leads to the separation and spread of tumor cells from primary tumors. In general, three types of EMT are recognized: type I—embryogenic EMT, type II-EMT associated with inflammation and tissue damage, and type III-EMT involved in tumor progression [36]. Deregulation of E-cadherin, N-cadherin, and vimentin expression are characteristic EMT markers. Vimentin, encoded by the VIM gene, is a filament protein with structural functions and vital importance for cell migration and proliferation $[37,38]$, and cadherins are transmembrane proteins that mediate cell-cell adhesion and play a crucial role in tissue morphogenesis and homeostasis [39]. Expressions of the above EMT markers are regulated by transcription factors from ZEB (ZEB1 and ZEB2), SNAIL (SNAI1 and SNAI2), and TWIST families [40-43]. Expression of these factors, and other EMT markers, is regulated by epigenetic modifications (DNA methylation and histone modifications) and by non-coding transcript elements [44-49].

The tumor microenvironment strongly impacts the metastatic process. It concerns particularly cancer-associated fibroblasts (CAFs), which produce several growth factors, e.g., EGF (epidermal growth factor) and HFG (hepatocyte growth factor) that promote tumor growth and progression [22,50]. Vascular endothelial growth factor (VEGF) is a cytokine essential for angiogenesis and lymphangiogenesis. The interaction between tumor and stromal cells can result in an increased VEGF expression [51,52]. Matrix metalloproteinases (MMPs) [53] and hypoxia-inducing factor-1 (HIF-1), inducing EMT in a hypoxic tumor environment, represent additional important factors in metastasis [54-56]. In the current chapter, we briefly described individual steps of EMT and thus metastases development. Many other molecules/signaling pathways are involved in this complex and crucial process.

An increasing number of molecular factors are is important for tumor progression, and the metastatic process is currently subject to discovery and further validation. Among these factors, regulatory non-coding elements, as microRNAs (miRNAs) and long non-coding RNAs (lncRNAs), seem to arise as potential biomarkers of metastases development. 


\section{The Role of Non-Protein-Coding Transcripts and Their Role in the Development of Ovarian Cancer Metastasis}

ncRNAs play substantial roles in the regulation of gene expression at both transcriptional and post-transcriptional levels. Due to this large functional importance, ncRNAs represent a promising potential as clinically relevant cancer biomarkers and therapeutic targets in OC $[13,57-60]$. The role of ncRNAs in the regulation of the EMT process seems especially crucial in the context of OC progression and the development of metastases. miRNAs, particularly the miR-200 family-miR-101 [45,61], miR-219-5p [62], and miR506 [63] - were demonstrated as effective regulators of EMT in OC through targeting and subsequent regulation of EMT-transcription factors (SNAIL, TWIST, and ZEB families). The roles of other non-coding entities such as, e.g., lncRNAs, are not yet fully understood due to publication of the first data in the last few years. IncARSR and CCAT1 seem to regulate the expression of the ZEB family [64,65]; HOXA11-AS and CCAT2 rule the TWIST family [46,47]; and PTAF, CCAT2, and MALAT1 the SNAIL family [66,67]. The schematic representation of ncRNAs implicated in the OC EMT process is in Figure 3. Taken together, out of all the ncRNA elements recognized to date that are important for the whole process of OC progression and metastases development, miRNAs and lncRNAs are the most attractive.

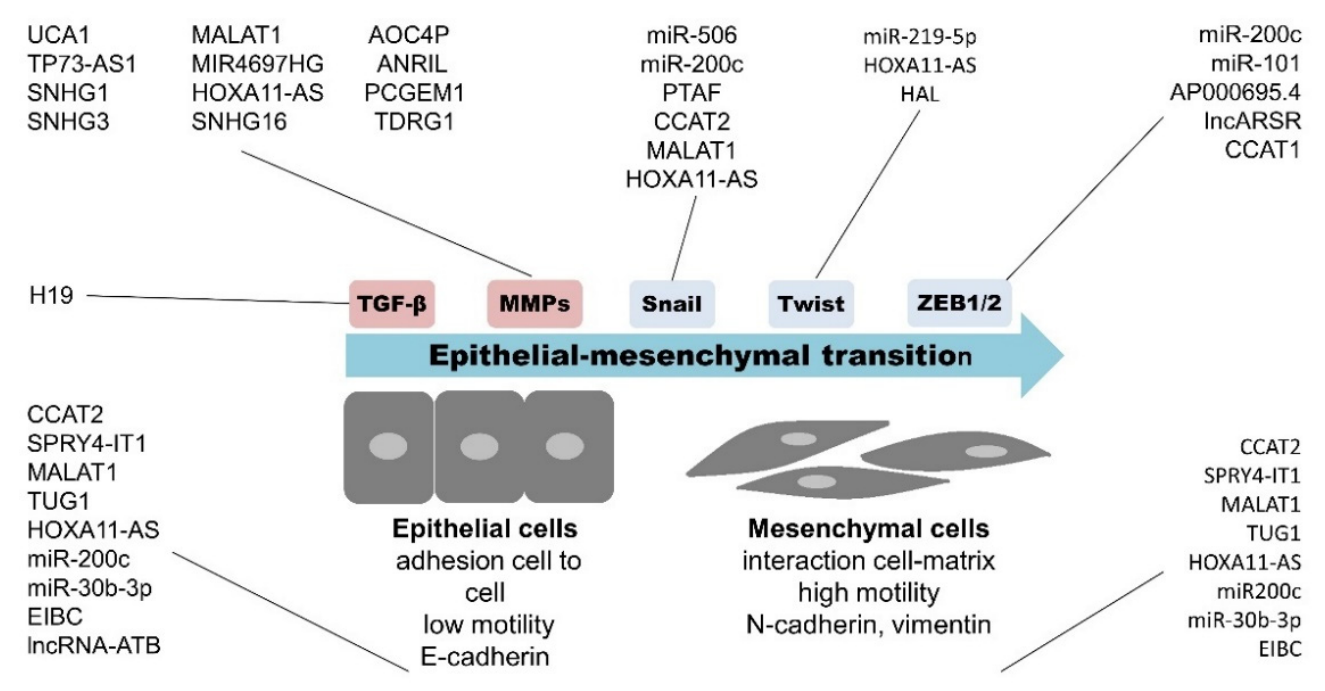

Figure 3. Schematic representation of ncRNA influencing epithelial-mesenchymal transition (EMT) process in OC. This chart shows ncRNAs elements-miRNAs and lncRNAs, which associate with EMT regulation. During EMT, adherent epithelial cells are changed to highly motile mesenchymal cells, capable of invading other places in human body. Few key molecules, i.e., E-cadherin, Ncadherin, and vimentin, whose expression is regulated by miRNAs and lncRNAs, characterize this process. Several ncRNAs regulate/interact with EMT-transcription factors (Snail, Twist, and ZEB families) and thus affect the EMT process. Other key players in EMT regulated by ncRNA are metalloproteinases (MMPs) and TGF- $\beta$.

\section{1. microRNA (miRNA) in Ovarian Cancer Progression}

miRNAs are 19-25-nucleotide-long RNAs interacting with target mRNA based on sequence complementarity between them. The binding of miRNAs to their target gene sequences in the $3^{\prime}$-untranslated region ( $\left.3^{\prime} \mathrm{UTR}\right)$ leads to the mRNA degradation or repression of mRNA translation (reviewed in [68]). miRNAs are functionally involved in proliferation pathways, apoptosis machinery, EMT process, or angiogenesis, and their expression is often deregulated in a variety of diseases, including cancer [68-71]. In cancer, miRNAs can act as tumor suppressors (e.g., miR-1299 and miR-506) or oncogenes (e.g., miR-125b), based on their binding partners [63,70,72].

More specifically, the well-known miRNA-200 family consisting of miR-200a, miR200b, miR-200c, miR-141, and miR-429 regulates the EMT process, critical for OC progres- 
sion via governing the expression of EMT transcription factors such as $Z E B 1, Z E B 2$, and EMT markers; E-cadherin; and vimentin in ovarian cancer cells [45,73,74]. Upregulation of miR-200a led to the silencing of important tumor suppressor gene PTEN in the OVCAR3 cell line in vitro [75]. Additionally, miR-506, interacting with transcription factors SNAI1 (indirectly) and SNAI2 (directly) or vimentin and N-cadherin, led to the inhibition of the EMT process. On the other hand, the interaction of miR-506 with TGF- $\beta$, another regulator of the EMT process, resulted in a TGF- $\beta$-induced EMT $[63,76]$. Another miRNA with a possible role in EMT regulation, miR-122, was related to expression changes of major EMT markers, i.e., E-cadherin, vimentin, and metalloproteinases (MMP2 and MMP14) [77].

Only a few studies comparing global miRNA expression profiles (miRNOM) of primary OC tumors and metastatic tissues are available. The expression profiles of overall miRNOM using microarray technologies revealed cassette of upregulated (miR-210, miR182, miR-200c, miR-23a, and let-7f) and downregulated (miR-145 and miR-214) miRNAs in OC effusions in comparison to OC primary tumors [73]. Another study, comparing nine pairs of primary serous OC tumors and omental metastases, reported seventeen differentially expressed miRNAs. Particularly miR-21, miR-150, and miR-146a were upregulated in omental metastases, suggesting the role in their metastases and chemotherapy resistance [78]. Using RNA-seq technology, Bachmayer-Heyda et al. [79] identified a profile of other 11 miRNAs associated with the metastatic spread of the HGSC OC tumor subtype (miR-706, miR-804, miR-1003, miR-1254, miR-1628, miR-1927, miR-2353, miR-2503, miR-2916, miR-3475, and miR-3784). Nevertheless, most studies focused on individual miRNAs, as summarized in Table 1. Concerning OC blood samples, miRNAs belong to the most studied entities in plasma or serum samples of patients. A higher level of miR-590-3p in OC plasma samples compared to control ones was observed [80], and lower expression of miR-145 in serum samples from OC patients $(n=70)$ was associated with disease progression [81]. Zuberi et al. observed an association between high expression of miR-125b in serum and the presence of OC lymph node and distant metastases [82]. Thus, based on the recently deciphered role of miRNAs in OC progression, future research in this direction is highly encouraged.

The role of miRNAs is further modulated by genetic variability, e.g., single nucleotide polymorphisms (SNPs) in miRNAs or target genes, and especially, changes in miRNA binding sites, which may have a pathological impact. SNP in the $3^{\prime}$ UTR region of the MDM4 gene (rs4245736, A > C) results in the creation of a new binding site for miR-191, and the presence of a $\mathrm{C}$ allele reduces the risk of OC development and suppresses its progression [83]. Another SNP rs11614913 (CC genotype) in miR-196a-2 increases the risk of OC and promotes cell migration and invasion [84]. Nevertheless, in a large study conducted on 3973 patients with invasive OC and 3276 control subjects, the authors have selected previously identified SNPs with OC risk association. The authors studied 226 SNPs localized within $15 \mathrm{~kb}$ of miRNAs processing genes DDX20, DROSHA, GEMIN4, or XPO5 and 23 SNPs in binding sites of miRNA targets (CAV1, COL18A1, E2F2, IL1R1, KRAS, and UGT2A3). No association between these SNPs and OC risk was observed after adjustment for European ancestry. This study shows the need for result validation on large study cohorts, not only in genetic variability studies [85]. As shown above, genetic variability in sequences crucial for the function of particular miRNAs should also be considered in the study of OC development and progression.

In recent years, functional in vitro and in vivo studies suggested a function of miRNAs in OC progression. The investigators observed the effects of particular miRNAs on the proliferation, migration, and invasive potential of tumor cells. For example, overexpression of miR-542-3p, miR-219-5p, miR-532, and miR-3064 suppressed the proliferation of OC cell line models in vitro [62,86-88]. The expression of miRNAs seems to be associated with cell migration. For example, overexpression of miR-222 and miR-205 enhances cell migration [89,90]. miRNAs can modulate the invasive behavior of OC cells, e.g., miR-106 inhibition suppresses cells invasion, miR-376a overexpression stimulates cell invasion, and, on the other hand, miR-145 overexpression suppresses cell invasion [91-93]. More miRNAs 
with an implicated role in OC are summarized in Table 1, including observed deregulation and predicted targets. More detailed information on miRNAs and their possible functions and roles in cellular processes, such as cancer cell proliferation, migration, and invasion, including experimental models and interactions with other molecules and target genes, is summarized in Table S1.

Table 1. miRNAs and their implication in ovarian cancer progression.

\begin{tabular}{|c|c|c|c|c|c|}
\hline \multicolumn{5}{|c|}{ Experimental Model } & \multirow[b]{2}{*}{ Reference } \\
\hline miRNA & $\begin{array}{c}\text { Patient } \\
\text { Samples }\end{array}$ & $\begin{array}{l}\text { Cell Lines, } \\
\text { Xenografts }\end{array}$ & Deregulation & Target & \\
\hline miR-9 & $\checkmark$ & $\checkmark$ & $\downarrow$ & NF-kB* & [94] \\
\hline $\mathrm{miR}-23 \mathrm{~b}$ & $\checkmark$ & $\checkmark$ & $\downarrow$ & RUNX2* & [95] \\
\hline miR-30b-3p & - & $\checkmark$ & $\downarrow$ & E-cadherin, $\beta$-catenin, vimentin ${ }^{* *}, \mathrm{CTHRC1}{ }^{*}$ & [44] \\
\hline miR-101 & - & $\checkmark$ & - & ZEB1, ZEB2* & [61] \\
\hline miR-106a & $\checkmark$ & $\checkmark$ & $\uparrow$ & PTEN ** & [92] \\
\hline miR-106b & $\checkmark$ & $\checkmark$ & $\downarrow$ & RhoC ** & [96] \\
\hline miR-122 & - & $\checkmark$ & - & P4HA1 * & [77] \\
\hline miR-138 & $\checkmark$ & $\checkmark$ & $\downarrow$ & SOX 4, HIF- $1 \alpha *$ & [97] \\
\hline miR-141 & $\checkmark$ & $\checkmark$ & $\uparrow$ & KLF12* & [98] \\
\hline miR-145 & $\checkmark$ & $\checkmark$ & $\downarrow$ & $\mathrm{MTDH}^{*}$ & [93] \\
\hline miR-193b & $\checkmark$ & $\checkmark$ & $\downarrow$ & $\mathrm{uPA}^{*}$ & [31] \\
\hline miR-199a-5p & - & $\checkmark$ & $\downarrow$ & NF-kB1 * & [99] \\
\hline miR-200a & $\checkmark$ & $\checkmark$ & $\uparrow$ & PTEN * & [75] \\
\hline \multirow[t]{2}{*}{$\mathrm{miR}-200 \mathrm{c}$} & - & $\checkmark$ & $\downarrow$ & ZEB1, vimentin, E-cadherin ** & [45] \\
\hline & - & $\checkmark$ & - & HOTAIR, Snail, E-cadherin ** & [100] \\
\hline miR-204 & $\checkmark$ & $\checkmark$ & - & BDNF* & [101] \\
\hline miR-205 & $\checkmark$ & $\checkmark$ & $\uparrow$ & SMAD4, PTEN * & [90] \\
\hline \multirow{2}{*}{ miR-219-5p } & - & $\checkmark$ & - & HMGA2 * & [87] \\
\hline & $\checkmark$ & $\checkmark$ & $\downarrow$ & Twist * & [62] \\
\hline miR-222 & $\checkmark$ & $\checkmark$ & $\uparrow$ & PTEN * & [89] \\
\hline miR-337-3p & $\checkmark$ & $\checkmark$ & $\downarrow$ & PIK3CA, PIK3CB * & [102] \\
\hline miR-376a & $\checkmark$ & $\checkmark$ & $\uparrow$ & KLF15, Caspase- 8 * & [91] \\
\hline miR-506 & $\checkmark$ & $\checkmark$ & $\uparrow$ & SNAIL2 * & [63] \\
\hline $\begin{array}{l}\mathrm{miR}-532 \\
\mathrm{miR}-3064\end{array}$ & $\checkmark$ & $\checkmark$ & $\downarrow$ & hTERT * & [88] \\
\hline $\begin{array}{l}\text { miR-3064 } \\
\text { miR-542-3p }\end{array}$ & $\checkmark$ & $\checkmark$ & $\downarrow$ & CDK14* & [86] \\
\hline miR-718 & $\checkmark$ & $\checkmark$ & $\downarrow$ & VEGF* & [103] \\
\hline miR-1299 & $\checkmark$ & $\checkmark$ & $\downarrow$ & TUG1, NOTCH3 * & [70] \\
\hline miR-4443 & $\checkmark$ & - & $\downarrow$ & - & \\
\hline miR-5159-3p & & & & & [104] \\
\hline
\end{tabular}

* target (connection) predicted by bioinformatics tools like TargetScan, DIANA-MicroT-CDS, miRWALK, miRDB, RNA22, PicTar, microRNA.org, PITA, miRNAnda, Starbase, etc. and/or dual-luciferase assay; ${ }^{* *}$ connection predicted by expression correlation, - not part of the study; $\downarrow$ expression downregulation between compared specimens; $\uparrow$ expression upregulation between compared specimens; $\checkmark$ included in the study.

\subsection{Long Non-Coding RNA (lncRNA) in Ovarian Cancer Progression}

lncRNAs, defined as transcripts longer than 200 nucleotides without protein-coding function, also have predominantly regulatory functions and exhibit highly tissue- and organ-specific expression patterns. The main mechanisms of function include regulation of transcription by interaction with coding and non-coding RNAs, proteins, chromatin, or recruitment of transcription factors. Moreover, lncRNAs affect mRNA stability, splicing, and translation processes. By interaction with protein partners, they influence their function and localization [105-109]. Besides interactions with protein-coding genes or proteins, lncRNAs interact with miRNAs as competing endogenous RNA (ceRNA) or "RNA sponges" and thus impose their regulatory effect on specific targets [110]. The regulatory function of lncRNAs influences many cellular processes such as proliferation, cell growth, viability, immortality or angiogenesis, and metastatic process. 
Cancer progression markers of OC, including lncRNAs, are identified mainly by comparing their expression in primary ovarian tumors and non-tumor tissues (summarized in Table 2, Table S2). Only a few studies have compared lncRNA expression profiles in primary OC tumors and metastatic tissues. The authors observed higher expression of CTD-2020K17.1 and LEF-AS1 and lower MEG3 expression in metastatic tissues of OC compared to primary tumor tissue. Knockdown of LEF1-AS1 in vitro suppressed the proliferation, migration, and invasive potential of SKOV3, OVCAR3 ovarian cancer cells [111-113]. The lncRNA profile, estimated by microarray analysis of expression of 4956 lncRNAs, revealed 583 upregulated and 578 downregulated lncRNAs between primary parental SKOV3 and metastatic (SKOV3.ip1EOC) sublines. The following seven lncRNAs were validated: MALAT1, H19, UCA1, CCAT1, LOC645249, LOC100128881, and LOC100292680 [114]. These lncRNAs could exert a role in OC metastatic progression. lncRNAs RP11-284N8.3.1 and AC104699.1 in the TCGA-OV dataset were differentially expressed during malignant $\mathrm{OC}$ progression, and functional analysis suggested their role in the tumor microenvironment and immune system [115].

In a search for new noninvasive tumor biomarkers, IncRNAs have also been studied in plasma or serum samples of OC patients. Expression of MALAT1 in plasma was significantly increased in metastatic OC patients compared with non-metastatic and healthy control samples. Moreover, OC patients with increased plasma MALAT1 had a poorer disease-free survival time [116]. lncRNA LINK-A was upregulated in OC tissue and serum samples compared to control ones. Besides, OC patients with metastases had a higher LINK-A expression in serum than patients without metastases [117]. The next study showed higher plasma LINK-A expression in OC patients with distant metastases [118]. Identification of new biomarkers in serum/plasma samples is also a part of clinical trials at present, e.g., the clinical trial NCT03738319 focused on ncRNA profile in exosomes of OC patients, last updated status showing patients recruitment [119].

The variability in genes encoding lncRNAs also plays an important role in the function of these non-coding elements. GWAS of approximately 18,000 invasive OC and 34,000 control samples of European ancestry revealed that invasive OC behavior was associated with 5294 SNPs, of which 1464 SNPs were mapped to 53 lncRNA genes [120]. Among particular genetic variants, SNP rs17427875 (minor T allele) in lncRNA HOXA11-AS1 is associated with reduced tumor growth in an in vivo mouse xenograft model based on the OC C13 cell line [121]. An association of the SNP rs920778 in HOTAIR with OC progression was reported in a case-control study of 329 OC patients and 680 controls from the Chinese population [122]. In this population, associations of other SNPs in HOTAIR (rs4759314 and 7958904) with a higher risk of OC progression were observed in 1000 OC patients and 1000 controls [123], demonstrating the potential of lncRNA genetic variability for the OC risk prediction.

The majority of studies on OC metastatic progression address the effect of lncRNAs on the EMT process through their interaction with specific EMT transcription factors and other molecules representing EMT. Association between the expression of EMT-related genes (specifically MMP2 and MMP9) and lncRNAs MALAT1 (study performed on OC tumor tissue samples $(n=64)$ and reference tissue $(n=30))$ and TP73-AS1 (study done on 60 pairs of OC tumor/control tissue) was observed. For MALAT1, it was the downregulation of MMP2 and MMP9, while for TP73-AS1, the effect was opposite [66,124]. IncRNA CCAT2 was associated with EMT inhibition and regulation of expression of EMT markers, namely, E-/N-cadherin and/or vimentin [46]. Expression of lncRNA HOXA11-AS1 is associated with downregulation of expression of EMT-related markers MMP2, MMP9, VEGF, Ncadherin, $\beta$-catenin, and vimentin and with upregulation of E-cadherin [47]. IncRNAs ANRIL and UCA1 downregulated expression of MMPs [125,126], and lncRNA AP000695.4 regulated transcription factor ZEB1 [127].

lncRNAs are thought to indirectly change the expression of EMT-related genes by interacting with miRNAs (as ceRNA or sponge, Table 2, Table S2) targeting these genes. For example, the above-described CCAT1 interacts with miR-152, miR-130b, and miR-490-3p, 
which regulate the expression of ADAM17, WNT1, STAT3, and ZEB1 genes [65,128,129]. MALAT1, NEAT1, and DQ786243 interact with miR-506, a well-known interaction partner of EMT transcription factors [130-132] (summarized in Table 2, Table S2).

Finally, lncRNAs also seem to be involved in specific signaling pathways related to different cellular processes important for proliferation. SNHG20 affected the Wnt/ $\beta$-catenin signaling pathway [133]. Other IncRNAs (MALAT1, HOXD-AS1, Linc-ROR, and HOTAIR) were associated with $\beta$-catenin inhibition [134-137], and, in contrast, this pathway was activated by lncRNA JPX inhibition [138]. The biologically relevant p53 pathway is regulated by lncRNA MEG3 through interaction of MEG3 with MDM2, leading to its suppression resulting in an increased level of p53 protein [139].

Table 2. IncRNAs and their implication in ovarian cancer progression.

\begin{tabular}{|c|c|c|c|c|c|}
\hline \multicolumn{6}{|c|}{ Experimental Model } \\
\hline IncRNA & $\begin{array}{c}\text { Patient } \\
\text { Samples }\end{array}$ & $\begin{array}{l}\text { Cell Lines, } \\
\text { Xenografts }\end{array}$ & Deregulation & Target & Reference \\
\hline ADAMTS9-AS2 & $\checkmark$ & $\checkmark$ & $\downarrow$ & miR-182-5p * & [140] \\
\hline \multirow[t]{2}{*}{ ANRIL } & $\checkmark$ & $\checkmark$ & $\begin{array}{r}r \\
\uparrow\end{array}$ & P15INK4b, Bcl-2 ** & [141] \\
\hline & $\checkmark$ & $\checkmark$ & $\uparrow$ & MET, MMP3 ** & [125] \\
\hline AOC4P & $\checkmark$ & $\checkmark$ & $\downarrow$ & MMP9, COL1A2 ** & [142] \\
\hline AP000695.4 & $\checkmark$ & $\checkmark$ & $\uparrow$ & $\mathrm{miR}-101$ ** & [127] \\
\hline \multicolumn{6}{|l|}{ ASAP1-IT1 } \\
\hline FAM215A & $d$ & - & $\uparrow$ & - & [143] \\
\hline \multicolumn{6}{|l|}{ LINC00472 } \\
\hline BLACAT1 & $\checkmark$ & $\checkmark$ & $\uparrow$ & miR-519d-3p * & [144] \\
\hline CASC9 & $\checkmark$ & $d$ & $\uparrow$ & miR-758-3p * & [145] \\
\hline \multirow[t]{2}{*}{ CCAT1 } & $\checkmark$ & $\checkmark$ & $\uparrow$ & miR-152, miR-130b * & [65] \\
\hline & $\checkmark$ & $\checkmark$ & $\uparrow$ & miR-490-3p * & [128] \\
\hline \multirow[t]{2}{*}{ CCAT2 } & $\checkmark$ & $\checkmark$ & $\uparrow$ & - & [146] \\
\hline & - & $\checkmark$ & $\uparrow$ & E/N-cadherin, Snail, Twist, Slug & [46] \\
\hline CDKN2BAS & $\checkmark$ & $d$ & $\uparrow$ & GAS6 ** & [147] \\
\hline CTD-2020K17.1 & $\checkmark$ & $d$ & $\uparrow$ & CARD11* & [111] \\
\hline DANCR & $\checkmark$ & $\checkmark$ & $\uparrow$ & miR-145 & [148] \\
\hline \multicolumn{6}{|l|}{ DNM3OS } \\
\hline MEG3 & $\checkmark$ & $\checkmark$ & $\uparrow$ & - & [149] \\
\hline \multicolumn{6}{|l|}{ MIAT } \\
\hline DQ786243 & $\checkmark$ & $\checkmark$ & $\uparrow$ & miR-506* & [132] \\
\hline DSCR8 & - & 1 & $\uparrow$ & $\mathrm{miR}-3192-5 \mathrm{p} / \mathrm{YY} 1$ * & [150] \\
\hline EBIC & $\checkmark$ & $\checkmark$ & $\uparrow$ & $\beta$-catenin, vimentin, E-cadherin ** & [151] \\
\hline EPB41L4A-AS2 & $\checkmark$ & $\checkmark$ & $\downarrow$ & miR-103a * & [152] \\
\hline FAL1 & - & $\checkmark$ & $\uparrow$ & PTEN, Akt ** & [153] \\
\hline \multirow[t]{2}{*}{ FAM83H-AS1 } & $\checkmark$ & $d$ & $\uparrow$ & - & [154] \\
\hline & $d$ & $d$ & - & $\mathrm{HuR}^{*}$ & [155] \\
\hline FEZF1-AS1 & $\checkmark$ & $\checkmark$ & $\uparrow$ & miR-130a-5p * & [156] \\
\hline FLVCR1-AS1 & $\checkmark$ & $\checkmark$ & $\uparrow$ & $\operatorname{miR}-513 *$ & [157] \\
\hline H19 & - & $\checkmark$ & $\uparrow$ & $\mathrm{miR}-370-3 p$ ** & [158] \\
\hline HAL & $\checkmark$ & $d$ & $\downarrow$ & Twist1 ${ }^{* *}$ & [159] \\
\hline HAND2-AS1 & $\checkmark$ & 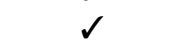 & $\downarrow$ & - & [160] \\
\hline НСР5 & $\checkmark$ & $\checkmark$ & $\uparrow$ & miR-525-5p * & [161] \\
\hline \multirow[t]{2}{*}{ HOTAIR } & - & $\checkmark$ & $\uparrow$ & miR-214, miR-217* * & [162] \\
\hline & $\checkmark$ & $\checkmark$ & $\uparrow$ & - & [163] \\
\hline HOTAIRM1 & $\checkmark$ & $\checkmark$ & $\downarrow$ & miR-106a-5p * & [164] \\
\hline HOTTIP & $\checkmark$ & $\checkmark$ & $\uparrow$ & $\beta$-catenin ** & [165] \\
\hline HOXA11-AS1 & $\checkmark$ & $\checkmark$ & $\uparrow$ & VEGF, MMP9, E-cadherin, Snail, Twist, & [47] \\
\hline \multirow{2}{*}{ HOXD-AS1 } & $\checkmark$ & $\checkmark$ & $\uparrow$ & miR-133-3p * & [135] \\
\hline & $\checkmark$ & $\checkmark$ & $\uparrow$ & miR-186-5p * & [166] \\
\hline JPX & $\checkmark$ & $d$ & $\uparrow$ & PI3K/AKT/mTOR pathway ** & [138] \\
\hline KCNQ1OT1 & - & $d$ & $\uparrow$ & miR-142-5p* & [167] \\
\hline
\end{tabular}


Table 2. Cont.

\begin{tabular}{|c|c|c|c|c|c|}
\hline \multicolumn{6}{|c|}{ Experimental Model } \\
\hline lncRNA & $\begin{array}{c}\text { Patient } \\
\text { Samples }\end{array}$ & $\begin{array}{l}\text { Cell Lines, } \\
\text { Xenografts }\end{array}$ & Deregulation & Target & Reference \\
\hline & $\checkmark$ & $\checkmark$ & $\uparrow$ & $\operatorname{miR}-212-3 p$ * & [168] \\
\hline LEF1-AS1 & $\checkmark$ & $\checkmark$ & $\uparrow$ & $\operatorname{miR}-1285-3 p$ * & [112] \\
\hline LINC00092 & $\checkmark$ & $\checkmark$ & $\uparrow$ & PFKFB2 ** & [169] \\
\hline LINC00176 & $\checkmark$ & $\checkmark$ & $\uparrow$ & BCL3 * & [170] \\
\hline LINC00339 & $\checkmark$ & $\checkmark$ & $\uparrow$ & $\operatorname{miR}-148 a-3 p$ * & [171] \\
\hline LINC00460 & $\checkmark$ & $\checkmark$ & $\uparrow$ & $\operatorname{miR}-338-3 p$ * & [172] \\
\hline LINC00504 & $\checkmark$ & $\checkmark$ & $\uparrow$ & $\operatorname{miR}-1244 *$, PKM2, HK2, PDK1 ** & [173] \\
\hline LINC00565 & $\checkmark$ & $\checkmark$ & $\uparrow$ & $\begin{array}{c}\text { cyclin D1, cyclin E1, CDK4, p16, p21 **, } \\
\text { GAS6 * }\end{array}$ & {$[174]$} \\
\hline LINC00963 & $\checkmark$ & $\checkmark$ & $\uparrow$ & miR-378g & [175] \\
\hline Linc-ROR & $\checkmark$ & $\checkmark$ & $\uparrow$ & Wnt $/ \beta$-catenin ** & [136] \\
\hline lncARSR & $\checkmark$ & $\checkmark$ & $\uparrow$ & $\begin{array}{c}\mathrm{HuR}, \beta \text {-catenin, ZEB1, ZEB2 **, miR-200 } \\
\text { family * }\end{array}$ & {$[64]$} \\
\hline \multirow[t]{2}{*}{ lncRNA-ATB } & - & $\checkmark$ & - & miR-204-3p * & [176] \\
\hline & - & $\checkmark$ & $\downarrow$ & p-STAT3, E-cadherin ** & [177] \\
\hline LncSOX4 & $\checkmark$ & $\checkmark$ & $\uparrow$ & - & [178] \\
\hline LOC100288181 & $\checkmark$ & $\checkmark$ & $\uparrow$ & miR-34a, miR-34c * & [179] \\
\hline LOXL1-AS1 & $\checkmark$ & $\checkmark$ & $\uparrow$ & miR-18b-5p * & [180] \\
\hline LUCAT1 & - & $\checkmark$ & $\uparrow$ & miR-199a-5p & [181] \\
\hline \multirow[t]{7}{*}{ MALAT1 } & - & $\checkmark$ & $\uparrow$ & $\mathrm{YAP} *$ & [182] \\
\hline & $\checkmark$ & - & $\uparrow$ & - & [116] \\
\hline & $\checkmark$ & $\checkmark$ & $\uparrow$ & - & [183] \\
\hline & $\checkmark$ & $\checkmark$ & $\uparrow$ & PI3K/AKT pathway ** & [66] \\
\hline & $\checkmark$ & $\checkmark$ & $\uparrow$ & $\operatorname{miR}-506^{* *}$ & [130] \\
\hline & $\checkmark$ & $\checkmark$ & $\uparrow$ & MMP13, MMP19, ADAMTS1 ** & [184] \\
\hline & $\checkmark$ & $\checkmark$ & $\uparrow$ & miR-200c * & [185] \\
\hline \multirow{5}{*}{ MEG3 } & $\checkmark$ & $\checkmark$ & $\downarrow$ & ATG3 ** & [113] \\
\hline & $\checkmark$ & $\checkmark$ & $\uparrow$ & PTEN ** & [186] \\
\hline & $\checkmark$ & $\checkmark$ & $\downarrow$ & $\operatorname{miR}-30 e-3 p$ & [187] \\
\hline & - & $\checkmark$ & $\downarrow$ & PTEN ** & [188] \\
\hline & $\checkmark$ & $\checkmark$ & $\downarrow$ & miR-205-5p & [189] \\
\hline MIF-AS1 & $\checkmark$ & $\checkmark$ & $\uparrow$ & miR-31-5p & [190] \\
\hline \multirow[t]{2}{*}{ MIR4435-2HG } & $\checkmark$ & $\checkmark$ & $\uparrow$ & $\operatorname{miR}-128-3 p$ * & [191] \\
\hline & $\checkmark$ & $\checkmark$ & $\uparrow$ & ROCK $2 * *$ & [192] \\
\hline MIR4697HG & $\checkmark$ & $\checkmark$ & $\uparrow$ & MMP9, ERK, AKT ** & [193] \\
\hline \multirow[t]{2}{*}{ NEAT1 } & $\checkmark$ & $\checkmark$ & $\uparrow$ & $\operatorname{miR}-506^{*}$ & [131] \\
\hline & $\checkmark$ & $\checkmark$ & $\uparrow$ & $\operatorname{miR}-382-3 p$ * & [194] \\
\hline NONHSAT076754 & $\checkmark$ & $\checkmark$ & $\uparrow$ & - & [195] \\
\hline PCA3 & $\checkmark$ & $\checkmark$ & $\uparrow$ & miR-106b-5p * & [196] \\
\hline PCAT-1 & $\checkmark$ & $\checkmark$ & $\uparrow$ & $\begin{array}{l}\text { Cyclin D1, CDK3, p53, BAX, vimentin, } \\
\text { miR-124-5p ** }\end{array}$ & {$[197]$} \\
\hline PCGEM1 & $\checkmark$ & $\checkmark$ & $\uparrow$ & RhoA, YAP, MMP2, Bcl-xL, P70S6K ** & [198] \\
\hline PTAF & $\checkmark$ & $\checkmark$ & - & miR-25, SNAIL2 ** & [67] \\
\hline \multirow[t]{2}{*}{ PVT1 } & $\checkmark$ & $\checkmark$ & $\uparrow$ & $\mathrm{EZH} 2 * *$ & [199] \\
\hline & $\checkmark$ & $\checkmark$ & $\uparrow$ & $\operatorname{miR}-133 a *$ & [200] \\
\hline \multirow[t]{2}{*}{ RHPN1-AS1 } & $\checkmark$ & $\checkmark$ & $\uparrow$ & $\operatorname{miR}-596 *$ & [201] \\
\hline & $\checkmark$ & $\checkmark$ & $\uparrow$ & $\operatorname{miR}-1299$ * & [202] \\
\hline SNHG1 & $\checkmark$ & $\checkmark$ & $\uparrow$ & MMP2, MMP9 ** & [203] \\
\hline SNHG3 & $\checkmark$ & $\checkmark$ & $\uparrow$ & GSK $\beta / \beta$-catenin signaling pathway ${ }^{* *}$ & [204] \\
\hline SNHG16 & $\checkmark$ & $\checkmark$ & $\uparrow$ & p-AKT, MMP9 ** & [205] \\
\hline SNHG20 & $\checkmark$ & $\checkmark$ & $\uparrow$ & $\beta$-catenin ** & [133] \\
\hline SOCAR & $\checkmark$ & $\checkmark$ & $\uparrow$ & Wnt $/ \beta$-catenin, MMP9 ** & [206] \\
\hline SPRY4-IT1 & $\checkmark$ & $\checkmark$ & $\downarrow$ & E-cadherin, $\mathrm{N}$-cadherin, vimentin ${ }^{* *}$ & [207] \\
\hline TP73-AS1 & $\checkmark$ & $\checkmark$ & $\uparrow$ & MMP2, MMP9 ** & [124] \\
\hline TC0101441 & $\checkmark$ & $\checkmark$ & $\uparrow$ & KiSS1 * & [208] \\
\hline
\end{tabular}


Table 2. Cont.

\begin{tabular}{|c|c|c|c|c|c|}
\hline \multicolumn{6}{|c|}{ Experimental Model } \\
\hline $\operatorname{lncRNA}$ & $\begin{array}{c}\text { Patient } \\
\text { Samples }\end{array}$ & $\begin{array}{l}\text { Cell Lines, } \\
\text { Xenografts }\end{array}$ & Deregulation & Target & Reference \\
\hline TDRG1 & $\checkmark$ & $\checkmark$ & $\uparrow$ & RhoC, R70S6K, Bcl-xL, MMP2 ** & [209] \\
\hline THOR & $\checkmark$ & $\checkmark$ & $\uparrow$ & IL-6/STAT3 ** & [210] \\
\hline TLR8-AS1 & $\checkmark$ & $\checkmark$ & $\uparrow$ & TLR8, NF-KB ** & [211] \\
\hline TONSL-AS1 & $\checkmark$ & $\checkmark$ & $\uparrow$ & miR-490-3p * & [212] \\
\hline TPT1-AS1 & $\checkmark$ & $\checkmark$ & $\uparrow$ & TPT1, PI3K/AKT ** & [213] \\
\hline \multirow[t]{2}{*}{ TTN-AS1 } & $\checkmark$ & $\checkmark$ & $\uparrow$ & miR-139-5p * & [214] \\
\hline & $\checkmark$ & $\checkmark$ & $\downarrow$ & miR-15b-5p * & [215] \\
\hline \multirow[t]{2}{*}{ TUG1 } & $\checkmark$ & $\checkmark$ & $\uparrow$ & $\mathrm{E} / \mathrm{N}$-cadherin, vimentin ${ }^{* *}$ & [216] \\
\hline & $\checkmark$ & $\checkmark$ & $\uparrow$ & MDM2 **, miR-29b-3p * & [217] \\
\hline UCA1 & $\checkmark$ & $\checkmark$ & $\uparrow$ & miR-485-5p * & [126] \\
\hline UNC5B-AS1 & $\checkmark$ & $\checkmark$ & $\uparrow$ & $\mathrm{EZH} 2$ * & [218] \\
\hline \multirow{2}{*}{$\begin{array}{c}\text { WDFY3-AS2 } \\
\text { XIST }\end{array}$} & $\checkmark$ & $\checkmark$ & $\downarrow$ & $\operatorname{miR}-18 a^{*}$ & [219] \\
\hline & $\checkmark$ & $\checkmark$ & $\uparrow$ & - & [220] \\
\hline
\end{tabular}

* target (connection) predicted by bioinformatics tools like TargetScan, DIANA-MicroT-CDS, miRWALK, miRDB, RNA22, PicTar, microRNA.org, PITA, miRNAnda, Starbase, etc. and/or dual-luciferase assay; ${ }^{* *}$ connection predicted by expression correlation, not part of the study; $\downarrow$ expression downregulation between compared specimens; $\uparrow$ expression upregulation between compared specimens; $\checkmark$ included in the study.

\section{Interplay between Regulators ncRNA and DNA Methylation}

The most typical epigenetic modifications involved in tumor transformation are DNA methylation and histone modification (specifically acetylation and methylation).

DNA methylation is a covalent modification based on attaching a methyl group to cytosine in a CG dinucleotide, often grouped into so-called CpG islands, localized predominantly in gene promoters. Hypermethylation leads to gene silencing, whereas hypomethylation is associated with disruption of genome stability. These changes are involved in the development of primary tumors and their subsequent progression. Hypermethylation and hypomethylation contribute to the development and progression of OC by altering the expression of a wide range of genes. In general, hypermethylation of genes involved in cell cycle regulation (CDKN2A and CDKN2B), DNA repair pathways (MGMT, $M L H 1$, and BRCA1), and transcription factors alone (GATA4 and GATA5) are important cancer-driver events. Methylation profile also interacts with other epigenetic regulatory elements such as miRNAs and lncRNAs [221,222] (Figure 4).

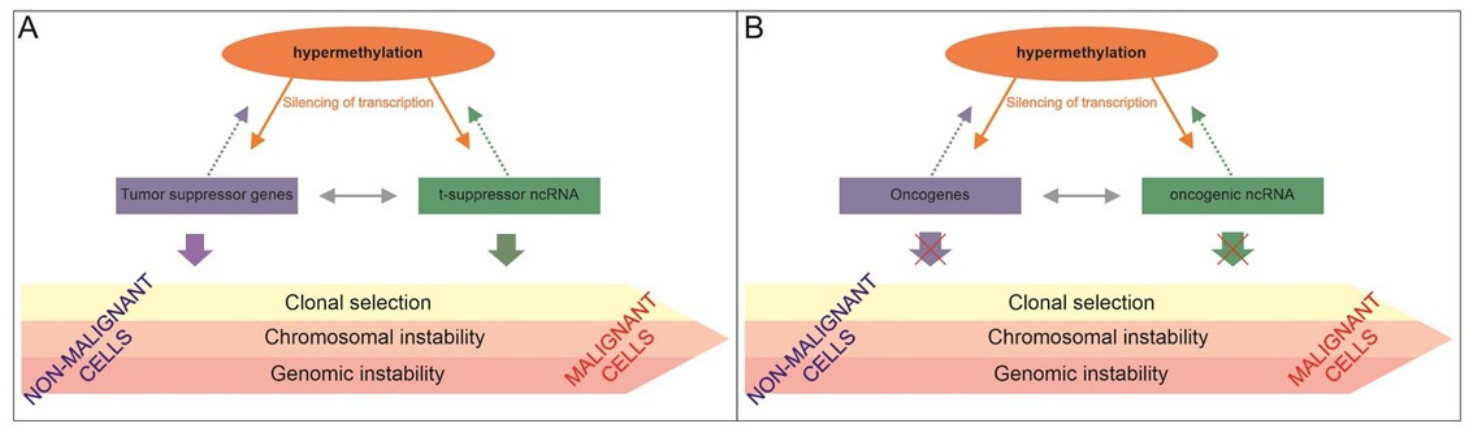

Figure 4. Simplified illustration of genetic and epigenetic interplay in ovary carcinogenesis. This complex process is reduced on the role of tumor suppressors (panel (A)) and oncogenes (panel (B)) in malignant transformation. Both panels indicate the effect of hypermethylation on transcription of tumor suppressor genes (A) and oncogenes (B) along with the involvement of non-coding RNAs. These may regulate tumor suppressing or oncogenic effects directly or in interaction with methylation. There are mutual regulations between non-coding RNAs and methylation status (full orange arrows) or the effect of non-coding RNAs on methylation status (dotted arrows), most likely via expression of DNA methyltransferases. 
Expression of genes for non-coding elements is likewise affected by DNA methylation, and, vice versa, ncRNA are also indicated as regulators of this epigenetic modification.

\section{1. miRNA-DNA Methylation Interplay}

Mutual regulation of miRNA and DNA methylation in carcinogenesis was already reviewed by Wang et al. for several solid cancer types. miRNA can regulate DNA methylation by modulating the expression of DNA methyltransferases (DNMT1, DNMT3a, DNMT3b) or methylation-related proteins MeCP2 (methyl CpG binding protein 2) and MBD2/MBD4 (methyl-CpG binding domain proteins 2/4) [223]. DNA methylation is also important in miRNA biogenesis and probably stands behind the higher cancer-driver phenotype of miRNA. It was shown that regions encoding miRNA with higher DNA methylation have higher cancer-driver-related phenotype than those from unmethylated DNA regions [224].

Regarding OC, downregulation of the miR-193a-3p expression caused by gene promoter hypermethylation was reported during tumor progression with increasing methylation level from low-grade $(n=50)$ to high-grade $(n=46)$. In this study, regulation of GRB7, ERBB4, SOS2, and KRAS in the MAPK/ERK signaling pathway by miR-193a-3p was observed. Based on this study, it seems that miR-193a-3p regulates the expression of four members of the MAPK/ERK pathway, and miR-193a-3p hypermethylation led to MAPK/ERK pathway upregulation [225]. Presence of OC metastases in the lymph nodes, peritoneum, and distant organs was recorded in connection with hypermethylation of ten miRNA genes (miR-121-4, -124-3, -125B-1, -127, -129-2, -137, -193A, -203A, -339, and -375). In disseminated OC tumors, only miR-203a and miR-375 were hypermethylated. The study was conducted on 76 pairs of OC tumor/control tissues, ten pairs of tumor/peritoneal metastases, and three tumor/control/peritoneal metastases samples [226]. The miR-199a$3 p$, with a putative tumor suppressor function, was hypermethylated in OC tissue and OC SKOV3 cells, but not in ovarian epithelial cells IOSE386. Overexpression of this miRNA in vitro impaired tumor cell proliferation, migration, and invasiveness [227]. Other possible progression markers are miR-9-1, miR-9-3, and miR-130b. Their methylation profile associated with differentiation, tumor size, and presence of metastases of OC, as assayed for on 54 pairs of OC tumor tissue (37 patients without metastases and 17 patients with metastases) and control tissue [228]. During TGF- $\beta 1$-induced EMT downregulation of TET3 in SKOV3/3AO, OC cell lines was detected. TET3 overexpression led to reverting of the TGF- $\beta 1$-induced EMT phenotype by demethylation of direct downstream target miR-30d (possible EMT suppressor function) [229]. On the contrary, a negative correlation between DNMT3A/3B expression with miR-29b in 15 OC tissue samples and in vitro was found. Based on in vitro experiments (SKOV3, A2780 cell lines), a double-negative regulation between DNMT3A/3B and miR-29b, was proposed-DNMT3A/3B are downregulated by miR-29b binding to their $3^{\prime}$ UTRs and knockdown of DNMT3A/3B lead to higher miR-29b expression through miR-29b gene promoter hypomethylation [230]. Li et al. observed suppression of miR-424-5p and miR-503-5p expression by their promoter hypermethylation in $44 \mathrm{OC}$ tumors compared to ten controls and confirmed this observation also by analysis of GEO datasets (GSE14407, GSE1520, GSE38666, and GSE40595). These miRNAs probably inhibit proliferation and migration by KIF23 suppression due to direct interaction in HO8910, HO8910PM, and A2780 OC cell lines [231]. On the contrary, Let-7a-3-associated expression changes were moderately affected by DNA methylation in a cohort of 214 OC patients, and no statistically significant association with disease progression was noted [232]. Based on studies with A2780/A2780CP OC cell lines, members of the miR-200 family (miR-200b and $\mathrm{miR}-200 \mathrm{c}$ ) are likely to modulate cell sensitivity to cisplatin by indirect interaction with DNMT1 and direct interaction with DNMT3A/3B [233]. The study on the SKOV3 cell line showed that miR-21, miR-203, and miR-205 were highly influenced by DNA methylation, as documented by demethylation treatment with $5^{\prime}$-aza-2'-deoxycytidine [234]. 


\subsection{IncRNA-DNA Methylation Interplay}

lncRNAs regulate epigenetic processes, DNA methylation, and histone acetylation as well, and are themselves strongly affected by DNA methylation. Interactions with methyltransferases/demethylases and acetyltransferases/deacetylases have been identified for several lncRNAs [107]. HOTAIR induced NF- $\mathrm{kB}$ in response to DNA damage and $M M P 6 / I L 6$ expression (target NF- $\mathrm{KB}$ genes) after platinum treatment, in vitro in a panel of sensitive (A2780, SKOV3, HEYC2, OV90, ISOE, OGROV, and OVMUNA) and resistant (A2780_CR50) OC cell lines in vitro. These results were also confirmed in the TCGA$\mathrm{OV}$ dataset (higher expression in OC patients with the recurrent disease compared to primary HGSC cases) [235]. The methylation status of $67 \mathrm{CpG}$ islands linked to HOTAIR was associated with poor survival of OC patients treated with platinum derivatives (six different sample sets, together 108 patients) [236]. Interaction between $\mathrm{H} 19$ and SAHH (S-adenosyl-L-homocysteine hydrolase) influenced the DNA methylation profile of several genes across the whole genome. A possible mechanism was proposed based on in vitro experiments on the HEK293 cell line. Knockdown of H19 activated SAHH, which increased methylation by DNMT3b [237].

IncRNA LOC134466 (ZFN300P1) hypermethylation was observed in $81 \%$ of serous OC tumors (from 27 samples) [238] and in cell lines SKOV3, OVCAR3, IGROV, OV90, COLO316, A2780, CaOV3, TOV112D, TOV21G, and EFO27, where the knockdown of this lncRNA reduced colony formation and proliferation. The ex vivo experiments demonstrated the feasible role of LOC134466 in attaching OC cells to the peritoneal membrane and enabling peritoneal expansion of OC metastatic lesions [239]. Based on TCGA data for 17 cancer types, epigenetic silencing of lncRNA MORT (ZNF667-AS1) in epithelial cells from 15 cancer types was extracted. Concerning OC, this was observed only for a few patients in contrast to breast, uterine, or cervix cancer patients [240]. A study focusing on the characterization of cis-acting lncRNA and DNA methylation showed five lncRNAs under strong methylation regulation (AC091814.2, AC141928.1, RP11-65J3.1-002, BX641110, and AF198444). Experiments on sensitive cell lines A2780/OVCAR3 and their platinum-resistant clones A2780-R/OVCAR3-R showed their possible involvement in cisplatin resistance [241].

Mutual connections and inter-regulation between ncRNA and DNA methylation are undeniable. However, it requires further clarification and mainly thorough in-depth investigation. Many potential interesting genes or DNA methylation changes have been discovered by robust high-throughput analyses and subsequently validated using in vitro and in vivo experiments. These are tools that permit us to understand the role of these targets in cell biology. The interplay between ncRNA-DNA methylation-gene expression is worthy of exploration to dissect their roles in human pathology and carcinogenesis on different levels of regulation.

\section{Conclusions and Future Perspectives}

This review addressed the involvement and mechanisms of action of non-coding RNA elements and their interplay with DNA methylation in the context of OC progression. Recognition of key players, being either lncRNAs or miRNAs, in OC progression may lead to the identification of prognostic biomarkers and formulation of novel therapeutic targets for individualized therapy.

Thanks to the advent of new robust techniques, researchers can now characterize the roles of DNA, RNA coding elements, and non-coding elements in tumor development and progression. In recent years, genomic research has brought the first useful biomarkers for OC management, e.g., patients bearing $B R C A 1 / B R C A 2$ mutations are sensitive to PARP inhibitors treatment [242]. Other promising biomarkers and tailored therapies, including the DNA repair system, are on the way (summarized in [12]). The field of ncRNA or epigenetic modifications in this setting is now open for investigations of new potential biomarkers. 
The role of miRNA in OC progression is more explored than that of lncRNA. Microarray and RNA sequencing studies identified novel potential miRNAs strongly deregulated in metastasis of ovarian carcinomas compared to primary tumors, e.g., the family miR-200, which interacts with EMT-related transcription factors [45,100]. Nevertheless, despite numerous other examples, the majority of findings were not replicated, and associations scatter among different cancer types, clinical stages, or therapeutic settings. Robust clinical trials designed to test the clinical validity and utility of these candidate prognostic and predictive biomarkers are urgently needed.

Although lncRNAs are still much less explored than miRNAs, some entities were found differentially expressed in pairs of primary tumors and metastatic samples. In general, it seems that cancer progression is predominantly associated with the upregulation of lncRNA expression. Experimental studies showed connections of lncRNAs with proliferation, invasion, migration, EMT, alterations of apoptosis, and metabolic pathways (Table 2, Table S2). Recent studies focused on the identification of complex miRNA-mRNA-IncRNA interactions increased our understanding of regulatory pathways in cancer progression (as summarized in Tables 1 and 2, Tables S1 and S2). Such integration of different regulatory levels may bring a much more solid picture of the molecular landscape of cancer and boost further efforts towards precision oncology.

DNA methylation is another effective epigenetic mechanism involved in OC progression as $\mathrm{CpG}$ methylation accumulates during its progression. Description of mutual interactions between miRNA/lncRNA and DNA methylation is important in the frame of the epigenetic regulation of gene expression. The advantage of DNA methylation is that its reversible character provides a promising therapeutic opportunity. This strategy is nowadays under investigation, and in some types of leukemia, demethylation therapy is already used. Uncovering these interactions may thus lead to novel therapeutic targets for a broader spectrum of cancers.

The concept of liquid biopsy, i.e., noninvasive testing using analysis of biomolecules in body fluids, mainly in serum and plasma specimens, represents the next key step to introduce experimentally identified biomarkers into clinical practice. Clinical trials focusing on the analysis of such biomarkers in body fluids are running. For example, the clinical trial NCT03738319 focuses on the expression level of lncRNA in serum samples of OC patients [119], and other clinical trials, e.g., NCT03742856, employ a multi-omics approach for tumor characterization and classification of its intrinsic heterogeneity or prediction of response to therapy [243].

On top of that, the search for biomarkers accelerated by clarifying their function using mechanistic studies based on in vitro (2D, 3D cultures, or organoids) and in vivo models (mainly mouse tumor cell xenografts or patient-derived xenografts). Patientderived xenograft models play an essential role in the determination of a specific patient's response to experimental therapy and the design of new drugs. Functional studies of lncRNA/miRNA interactions and their cellular functions broaden, together with in silico prediction and analysis tools, comprehension of regulatory networks in cancer progression.

We believe that additional and more robust studies on the interactive network of miRNA, IncRNA, and DNA methylation together will help to identify new prognostic and predictive biomarkers and therapeutic targets specific for OC and foster the present era of precision oncology.

Supplementary Materials: The following are available online at https:/ /www.mdpi.com/article/10 $.3390 /$ cancers13081839/s1, Supplementary Table S1: Detailed information about miRNA implication in ovarian cancer progression, Supplementary Table S2: Detailed information about lncRNA implication in ovarian cancer progression.

Author Contributions: Conceptualization, K.S. and R.V.; writing—original draft preparation, K.S.; writing-review and editing, R.V., P.V. and P.S.; visualization, K.S.; supervision, R.V., P.V. and L.R., P.S. All authors have read and agreed to the published version of the manuscript. 
Funding: This work was supported by Czech Science Foundation-project no. 19-10543S to P.V., Czech Health Research Council-project no. NU20-09-00174 to R.V., Grant Agency of Charles Universityproject no. GAUK-1074120 to K.S, Charles University research program PROGRES Q28 to L.R., ERDF/ESF project "International competitiveness of NIPH in research, development and education in alternative toxicological methods" (No. CZ.02.1.01/0.0/0.0/16_019/0000860) to P.S.

Conflicts of Interest: The authors declare no conflict of interest.

$\begin{array}{ll}\text { Abbreviations } \\ \text { CAFs } & \begin{array}{l}\text { cancer-associated fibroblasts } \\ \text { cempeting endogenous RNA }\end{array} \\ \text { CT } & \begin{array}{l}\text { computed tomography } \\ \text { circulating tumor cells }\end{array} \\ \text { CTCs } & \text { disease-free survival } \\ \text { DFS } & \text { epithelial-mesenchymal transition } \\ \text { EMT } & \text { International Federation of Gynecology and Obstetrics } \\ \text { FIGO } & \text { Gene Expression Omnibus database } \\ \text { GEO } & \text { genome wide association study } \\ \text { GWAS } & \text { high-grade serous carcinoma } \\ \text { HGSC } & \text { long non-coding RNA } \\ \text { lncRNA } & \text { messenger RNA } \\ \text { mRNA } & \text { micro-RNA } \\ \text { miRNA } & \text { non-coding RNA } \\ \text { ncRNA } & \text { non } \\ \text { OC } & \text { ovarian cancer } \\ \text { OS } & \text { overall survival } \\ \text { PFS } & \text { progression-free survival } \\ \text { SNP } & \text { single nucleotide polymorphism } \\ \text { TCGA } & \text { The Cancer Genome Atlas } \\ \text { 3'UTR } & \text { three prime untranslated region } \\ & \end{array}$

\section{References}

1. Bray, F.; Ferlay, J.; Soerjomataram, I.; Siegel, R.L.; Torre, L.A.; Jemal, A. Global Cancer Statistics 2018: GLOBOCAN Estimates of Incidence and Mortality Worldwide for 36 Cancers in 185 Countries. CA Cancer J. Clin. 2018, 68, 394-424. [CrossRef]

2. Prat, J.; FIGO Committee on Gynecologic Oncology. Abridged Republication of FIGO's Staging Classification for Cancer of the Ovary, Fallopian Tube, and Peritoneum. Cancer 2015, 121, 3452-3454. [CrossRef] [PubMed]

3. Rojas, V.; Hirshfield, K.M.; Ganesan, S.; Rodriguez-Rodriguez, L. Molecular Characterization of Epithelial Ovarian Cancer: Implications for Diagnosis and Treatment. Int. J. Mol. Sci. 2016, 17, 2113. [CrossRef] [PubMed]

4. Matz, M.; Coleman, M.P.; Carreira, H.; Salmerón, D.; Chirlaque, M.D.; Allemani, C.; CONCORD Working Group. Worldwide Comparison of Ovarian Cancer Survival: Histological Group and Stage at Diagnosis (CONCORD-2). Gynecol. Oncol. 2017, 144, 396-404. [CrossRef] [PubMed]

5. Ovarian Cancer Survival Rates. Ovarian Cancer Prognosis. Available online: https://www.cancer.org/cancer/ovarian-cancer/ detection-diagnosis-staging/survival-rates.html (accessed on 9 August 2020).

6. Kim, A.; Ueda, Y.; Naka, T.; Enomoto, T. Therapeutic Strategies in Epithelial Ovarian Cancer. J. Exp. Clin. Cancer Res. 2012, 31, 14. [CrossRef]

7. Cortez, A.J.; Tudrej, P.; Kujawa, K.A.; Lisowska, K.M. Advances in Ovarian Cancer Therapy. Cancer Chemother. Pharmacol. 2018, 81, 17-38. [CrossRef]

8. Lisio, M.-A.; Fu, L.; Goyeneche, A.; Gao, Z.-H.; Telleria, C. High-Grade Serous Ovarian Cancer: Basic Sciences, Clinical and Therapeutic Standpoints. Int. J. Mol. Sci. 2019, 20, 952. [CrossRef]

9. Luvero, D.; Milani, A.; Ledermann, J.A. Treatment Options in Recurrent Ovarian Cancer: Latest Evidence and Clinical Potential. Ther. Adv. Med. Oncol. 2014, 6, 229-239. [CrossRef]

10. Matulonis, U.A.; Sood, A.K.; Fallowfield, L.; Howitt, B.E.; Sehouli, J.; Karlan, B.Y. Ovarian Cancer. Nat. Rev. Dis. Primer 2016, 2, 16061. [CrossRef]

11. Kurman, R.J.; Shih, I.-M. The Dualistic Model of Ovarian Carcinogenesis: Revisited, Revised, and Expanded. Am. J. Pathol. 2016, 186, 733-747. [CrossRef]

12. Tomasova, K.; Cumova, A.; Seborova, K.; Horak, J.; Koucka, K.; Vodickova, L.; Vaclavikova, R.; Vodicka, P. DNA Repair and Ovarian Carcinogenesis: Impact on Risk, Prognosis and Therapy Outcome. Cancers 2020, 12, 1713. [CrossRef]

13. Anastasiadou, E.; Jacob, L.S.; Slack, F.J. Non-Coding RNA Networks in Cancer. Nat. Rev. Cancer 2018, 18, 5-18. [CrossRef] [PubMed] 
14. Nakayama, K.; Nakayama, N.; Katagiri, H.; Miyazaki, K. Mechanisms of Ovarian Cancer Metastasis: Biochemical Pathways. Int. J. Mol. Sci. 2012, 13, 11705-11717. [CrossRef] [PubMed]

15. Lengyel, E. Ovarian Cancer Development and Metastasis. Am. J. Pathol. 2010, 177, 1053-1064. [CrossRef] [PubMed]

16. Yeung, T.-L.; Leung, C.S.; Yip, K.-P.; Au Yeung, C.L.; Wong, S.T.C.; Mok, S.C. Cellular and Molecular Processes in Ovarian Cancer Metastasis. A Review in the Theme: Cell and Molecular Processes in Cancer Metastasis. Am. J. Physiol. Cell Physiol. 2015, 309, C444-C456. [CrossRef]

17. Deng, K.; Yang, C.; Tan, Q.; Song, W.; Lu, M.; Zhao, W.; Lou, G.; Li, Z.; Li, K.; Hou, Y. Sites of Distant Metastases and Overall Survival in Ovarian Cancer: A Study of 1481 Patients. Gynecol. Oncol. 2018, 150, 460-465. [CrossRef]

18. Klymenko, Y.; Johnson, J.; Bos, B.; Lombard, R.; Campbell, L.; Loughran, E.; Stack, M.S. Heterogeneous Cadherin Expression and Multicellular Aggregate Dynamics in Ovarian Cancer Dissemination. Neoplasia 2017, 19, 549-563. [CrossRef] [PubMed]

19. Madsen, C.D.; Ferraris, G.M.S.; Andolfo, A.; Cunningham, O.; Sidenius, N. UPAR-Induced Cell Adhesion and Migration: Vitronectin Provides the Key. J. Cell Biol. 2007, 177, 927-939. [CrossRef]

20. Vergara, D.; Merlot, B.; Lucot, J.-P.; Collinet, P.; Vinatier, D.; Fournier, I.; Salzet, M. Epithelial-Mesenchymal Transition in Ovarian Cancer. Cancer Lett. 2010, 291, 59-66. [CrossRef]

21. Nakatsuka, E.; Sawada, K.; Nakamura, K.; Yoshimura, A.; Kinose, Y.; Kodama, M.; Hashimoto, K.; Mabuchi, S.; Makino, H.; Morii, E.; et al. Plasminogen Activator Inhibitor-1 Is an Independent Prognostic Factor of Ovarian Cancer and IMD-4482, a Novel Plasminogen Activator Inhibitor-1 Inhibitor, Inhibits Ovarian Cancer Peritoneal Dissemination. Oncotarget 2017, 8, 89887-89902. [CrossRef]

22. Zhou, H.Y.; Pon, Y.L.; Wong, A.S.T. Synergistic Effects of Epidermal Growth Factor and Hepatocyte Growth Factor on Human Ovarian Cancer Cell Invasion and Migration: Role of Extracellular Signal-Regulated Kinase 1/2 and P38 Mitogen-Activated Protein Kinase. Endocrinology 2007, 148, 5195-5208. [CrossRef]

23. Belotti, D.; Paganoni, P.; Manenti, L.; Garofalo, A.; Marchini, S.; Taraboletti, G.; Giavazzi, R. Matrix Metalloproteinases (MMP9 and MMP2) Induce the Release of Vascular Endothelial Growth Factor (VEGF) by Ovarian Carcinoma Cells: Implications for Ascites Formation. Cancer Res. 2003, 63, 5224-5229.

24. Liu, Y.; Ren, C.-C.; Yang, L.; Xu, Y.-M.; Chen, Y.-N. Role of CXCL12-CXCR4 Axis in Ovarian Cancer Metastasis and CXCL12CXCR4 Blockade with AMD3100 Suppresses Tumor Cell Migration and Invasion in Vitro: LIU ET AL. J. Cell. Physiol. 2019, 234, 3897-3909. [CrossRef]

25. Zhou, J.; Du, Y.; Lu, Y.; Luan, B.; Xu, C.; Yu, Y.; Zhao, H. CD44 Expression Predicts Prognosis of Ovarian Cancer Patients Through Promoting Epithelial-Mesenchymal Transition (EMT) by Regulating Snail, ZEB1, and Caveolin-1. Front. Oncol. 2019, 9, 802. [CrossRef]

26. Cheng, K.W.; Lahad, J.P.; Kuo, W.-L.; Lapuk, A.; Yamada, K.; Auersperg, N.; Liu, J.; Smith-McCune, K.; Lu, K.H.; Fishman, D.; et al. The RAB25 Small GTPase Determines Aggressiveness of Ovarian and Breast Cancers. Nat. Med. 2004, 10, 1251-1256. [CrossRef] [PubMed]

27. Kamat, A.A.; Fletcher, M.; Gruman, L.M.; Mueller, P.; Lopez, A.; Landen, C.N.; Han, L.; Gershenson, D.M.; Sood, A.K. The Clinical Relevance of Stromal Matrix Metalloproteinase Expression in Ovarian Cancer. Clin. Cancer Res. Off. J. Am. Assoc. Cancer Res. 2006, 12, 1707-1714. [CrossRef]

28. Sawada, K.; Mitra, A.K.; Radjabi, A.R.; Bhaskar, V.; Kistner, E.O.; Tretiakova, M.; Jagadeeswaran, S.; Montag, A.; Becker, A.; Kenny, H.A.; et al. Loss of E-Cadherin Promotes Ovarian Cancer Metastasis via $\alpha_{5}$-Integrin, Which Is a Therapeutic Target. Cancer Res. 2008, 68, 2329-2339. [CrossRef] [PubMed]

29. Bian, D.; Su, S.; Mahanivong, C.; Cheng, R.K.; Han, Q.; Pan, Z.K.; Sun, P.; Huang, S. Lysophosphatidic Acid Stimulates Ovarian Cancer Cell Migration via a Ras-MEK Kinase 1 Pathway. Cancer Res. 2004, 64, 4209-4217. [CrossRef] [PubMed]

30. Cai, S.; Zhang, P.; Dong, S.; Li, L.; Cai, J.; Xu, M. Downregulation of SPINK13 Promotes Metastasis by Regulating UPA in Ovarian Cancer Cells. Cell. Physiol. Biochem. 2018, 45, 1061-1071. [CrossRef]

31. Mitra, A.K.; Chiang, C.Y.; Tiwari, P.; Tomar, S.; Watters, K.M.; Peter, M.E.; Lengyel, E. Microenvironment-Induced Downregulation of MiR-193b Drives Ovarian Cancer Metastasis. Oncogene 2015, 34, 5923-5932. [CrossRef]

32. Tomar, S.; Plotnik, J.P.; Haley, J.; Scantland, J.; Dasari, S.; Sheikh, Z.; Emerson, R.; Lenz, D.; Hollenhorst, P.C.; Mitra, A.K. ETS1 Induction by the Microenvironment Promotes Ovarian Cancer Metastasis through Focal Adhesion Kinase. Cancer Lett. 2018, 414, 190-204. [CrossRef]

33. Huang, S.-P.; Wu, M.-S.; Shun, C.-T.; Wang, H.-P.; Lin, M.-T.; Kuo, M.-L.; Lin, J.-T. Interleukin-6 Increases Vascular Endothelial Growth Factor and Angiogenesis in Gastric Carcinoma. J. Biomed. Sci. 2004, 11, 517-527. [CrossRef]

34. Watanabe, T.; Hashimoto, T.; Sugino, T.; Soeda, S.; Nishiyama, H.; Morimura, Y.; Yamada, H.; Goodison, S.; Fujimori, K. Production of IL1-Beta by Ovarian Cancer Cells Induces Mesothelial Cell Beta1-Integrin Expression Facilitating Peritoneal Dissemination. J. Ovarian Res. 2012, 5, 7. [CrossRef]

35. Pradeep, S.; Kim, S.W.; Wu, S.Y.; Nishimura, M.; Chaluvally-Raghavan, P.; Miyake, T.; Pecot, C.V.; Kim, S.-J.; Choi, H.J.; Bischoff, F.Z.; et al. Hematogenous Metastasis of Ovarian Cancer: Rethinking Mode of Spread. Cancer Cell 2014, 26, 77-91. [CrossRef] [PubMed]

36. Kalluri, R.; Weinberg, R.A. The Basics of Epithelial-Mesenchymal Transition. J. Clin. Investig. 2009, 119, 1420-1428. [CrossRef] [PubMed] 
37. Battaglia, R.A.; Delic, S.; Herrmann, H.; Snider, N.T. Vimentin on the Move: New Developments in Cell Migration. F1000Research 2018, 7. [CrossRef] [PubMed]

38. Liu, C.-Y.; Lin, H.-H.; Tang, M.-J.; Wang, Y.-K. Vimentin Contributes to Epithelial-Mesenchymal Transition Cancer Cell Mechanics by Mediating Cytoskeletal Organization and Focal Adhesion Maturation. Oncotarget 2015, 6, 15966-15983. [CrossRef] [PubMed]

39. Maître, J.-L.; Heisenberg, C.-P. Three Functions of Cadherins in Cell Adhesion. Curr. Biol. 2013, 23, R626-R633. [CrossRef]

40. Wu, D.; Liu, L.; Ren, C.; Kong, D.; Zhang, P.; Jin, X.; Wang, T.; Zhang, G. Epithelial-Mesenchymal Interconversions and the Regulatory Function of the ZEB Family during the Development and Progression of Ovarian Cancer. Oncol. Lett. 2016, 11, 1463-1468. [CrossRef]

41. Sánchez-Tilló, E.; Lázaro, A.; Torrent, R.; Cuatrecasas, M.; Vaquero, E.C.; Castells, A.; Engel, P.; Postigo, A. ZEB1 Represses E-Cadherin and Induces an EMT by Recruiting the SWI/SNF Chromatin-Remodeling Protein BRG1. Oncogene 2010, 29, 3490-3500. [CrossRef]

42. Batlle, E.; Sancho, E.; Francí, C.; Domínguez, D.; Monfar, M.; Baulida, J.; García de Herreros, A. The Transcription Factor Snail Is a Repressor of E-Cadherin Gene Expression in Epithelial Tumour Cells. Nat. Cell Biol. 2000, 2, 84-89. [CrossRef] [PubMed]

43. Kurrey, N.K.; K, A.; Bapat, S.A. Snail and Slug Are Major Determinants of Ovarian Cancer Invasiveness at the Transcription Level. Gynecol. Oncol. 2005, 97, 155-165. [CrossRef] [PubMed]

44. Li, Y.; Zhou, J.; Wang, J.; Chen, X.; Zhu, Y.; Chen, Y. Mir-30b-3p Affects the Migration and Invasion Function of Ovarian Cancer Cells by Targeting the CTHRC1 Gene. Biol. Res. 2020, 53, 10. [CrossRef]

45. Chen, D.; Zhang, Y.; Wang, J.; Chen, J.; Yang, C.; Cai, K.; Wang, X.; Shi, F.; Dou, J. MicroRNA-200c Overexpression Inhibits Tumorigenicity and Metastasis of CD117+CD44+ Ovarian Cancer Stem Cells by Regulating Epithelial-Mesenchymal Transition. J. Ovarian Res. 2013, 6, 50. [CrossRef] [PubMed]

46. Wang, B.; Liu, M.; Zhuang, R.; Jiang, J.; Gao, J.; Wang, H.; Chen, H.; Zhang, Z.; Kuang, Y.; Li, P. Long Non-Coding RNA CCAT2 Promotes Epithelial-Mesenchymal Transition Involving Wnt/ $\beta$-Catenin Pathway in Epithelial Ovarian Carcinoma Cells. Oncol. Lett. 2018, 15, 3369-3375. [CrossRef]

47. Yim, G.W.; Kim, H.J.; Kim, L.K.; Kim, S.W.; Kim, S.; Nam, E.J.; Kim, Y.T. Long Non-Coding RNA HOXA11 Antisense Promotes Cell Proliferation and Invasion and Predicts Patient Prognosis in Serous Ovarian Cancer. Cancer Res. Treat. Off. J. Korean Cancer Assoc. 2017, 49, 656-668. [CrossRef] [PubMed]

48. Lombaerts, M.; van Wezel, T.; Philippo, K.; Dierssen, J.W.F.; Zimmerman, R.M.E.; Oosting, J.; van Eijk, R.; Eilers, P.H.; van de Water, B.; Cornelisse, C.J.; et al. E-Cadherin Transcriptional Downregulation by Promoter Methylation but Not Mutation Is Related to Epithelial-to-Mesenchymal Transition in Breast Cancer Cell Lines. Br. J. Cancer 2006, 94, 661-671. [CrossRef]

49. Peixoto, P.; Etcheverry, A.; Aubry, M.; Missey, A.; Lachat, C.; Perrard, J.; Hendrick, E.; Delage-Mourroux, R.; Mosser, J.; Borg, C.; et al. EMT Is Associated with an Epigenetic Signature of ECM Remodeling Genes. Cell Death Dis. 2019, 10, 205. [CrossRef]

50. Zhang, Y.; Tang, H.; Cai, J.; Zhang, T.; Guo, J.; Feng, D.; Wang, Z. Ovarian Cancer-Associated Fibroblasts Contribute to Epithelial Ovarian Carcinoma Metastasis by Promoting Angiogenesis, Lymphangiogenesis and Tumor Cell Invasion. Cancer Lett. 2011, 303, 47-55. [CrossRef]

51. Bekes, I.; Friedl, T.W.P.; Köhler, T.; Möbus, V.; Janni, W.; Wöckel, A.; Wulff, C. Does VEGF Facilitate Local Tumor Growth and Spread into the Abdominal Cavity by Suppressing Endothelial Cell Adhesion, Thus Increasing Vascular Peritoneal Permeability Followed by Ascites Production in Ovarian Cancer? Mol. Cancer 2016, 15, 13. [CrossRef]

52. Yang, X.; Zhang, Y.; Hosaka, K.; Andersson, P.; Wang, J.; Tholander, F.; Cao, Z.; Morikawa, H.; Tegnér, J.; Yang, Y.; et al. VEGF-B Promotes Cancer Metastasis through a VEGF-A-Independent Mechanism and Serves as a Marker of Poor Prognosis for Cancer Patients. Proc. Natl. Acad. Sci. USA 2015, 112, E2900-E2909. [CrossRef]

53. Wang, S.; Jia, J.; Liu, D.; Wang, M.; Wang, Z.; Li, X.; Wang, H.; Rui, Y.; Liu, Z.; Guo, W.; et al. Matrix Metalloproteinase Expressions Play Important Role in Prediction of Ovarian Cancer Outcome. Sci. Rep. 2019, 9, 11677. [CrossRef]

54. Imai, T.; Horiuchi, A.; Wang, C.; Oka, K.; Ohira, S.; Nikaido, T.; Konishi, I. Hypoxia Attenuates the Expression of E-Cadherin via Up-Regulation of SNAIL in Ovarian Carcinoma Cells. Am. J. Pathol. 2003, 163, 1437-1447. [CrossRef]

55. Zhang, H.; Yang, Q.; Lian, X.; Jiang, P.; Cui, J. Hypoxia-Inducible Factor-1 $\alpha$ (HIF-1 $\alpha$ ) Promotes Hypoxia-Induced Invasion and Metastasis in Ovarian Cancer by Targeting Matrix Metallopeptidase 13 (MMP13). Med. Sci. Monit. 2019, 25, 7202-7208. [CrossRef] [PubMed]

56. Wang, Y.; Ma, J.; Shen, H.; Wang, C.; Sun, Y.; Howell, S.B.; Lin, X. Reactive Oxygen Species Promote Ovarian Cancer Progression via the HIF-1 $\alpha /$ LOX/E-Cadherin Pathway. Oncol. Rep. 2014, 32, 2150-2158. [CrossRef] [PubMed]

57. Iyer, M.K.; Niknafs, Y.S.; Malik, R.; Singhal, U.; Sahu, A.; Hosono, Y.; Barrette, T.R.; Prensner, J.R.; Evans, J.R.; Zhao, S.; et al. The Landscape of Long Noncoding RNAs in the Human Transcriptome. Nat. Genet. 2015, 47, 199-208. [CrossRef] [PubMed]

58. Hon, C.-C.; Ramilowski, J.A.; Harshbarger, J.; Bertin, N.; Rackham, O.J.L.; Gough, J.; Denisenko, E.; Schmeier, S.; Poulsen, T.M.; Severin, J.; et al. An Atlas of Human Long Non-Coding RNAs with Accurate 5' Ends. Nature 2017, 543, 199-204. [CrossRef] [PubMed]

59. Zhou, X.-Y.; Luo, B.; Jiang, Z.-K.; Xie, Y.-K.; Wu, F.-C.; Huang, J.-Q.; Chen, J.-S. Non-Coding RNAS and Colorectal Cancer Liver Metastasis. Mol. Cell. Biochem. 2020. [CrossRef]

60. Forterre, A.; Komuro, H.; Aminova, S.; Harada, M. A Comprehensive Review of Cancer MicroRNA Therapeutic Delivery Strategies. Cancers 2020, 12, 1852. [CrossRef] 
61. GUO, F.; COGDELL, D.; HU, L.; YANG, D.; SOOD, A.K.; XUE, F.; ZHANG, W. MiR-101 Suppresses the Epithelial-to-Mesenchymal Transition by Targeting ZEB1 and ZEB2 in Ovarian Carcinoma. Oncol. Rep. 2014, 31, 2021-2028. [CrossRef]

62. Wei, C.; Zhang, X.; He, S.; Liu, B.; Han, H.; Sun, X. MicroRNA-219-5p Inhibits the Proliferation, Migration, and Invasion of Epithelial Ovarian Cancer Cells by Targeting the Twist/Wnt/ $\beta$-Catenin Signaling Pathway. Gene 2017, 637, 25-32. [CrossRef]

63. Sun, Y.; Hu, L.; Zheng, H.; Bagnoli, M.; Guo, Y.; Rupaimoole, R.; Rodriguez-Aguayo, C.; Lopez-Berestein, G.; Ji, P.; Chen, K.; et al MiR-506 Inhibits Multiple Targets in the Epithelial-to-Mesenchymal Transition Network and Is Associated with Good Prognosis in Epithelial Ovarian Cancer. J. Pathol. 2015, 235, 25-36. [CrossRef]

64. Shu, C.; Yan, D.; Mo, Y.; Gu, J.; Shah, N.; He, J. Long Noncoding RNA LncARSR Promotes Epithelial Ovarian Cancer Cell Proliferation and Invasion by Association with HuR and MiR-200 Family. Am. J. Cancer Res. 2018, 8, 981-992.

65. Cao, Y.; Shi, H.; Ren, F.; Jia, Y.; Zhang, R. Long Non-Coding RNA CCAT1 Promotes Metastasis and Poor Prognosis in Epithelial Ovarian Cancer. Exp. Cell Res. 2017, 359, 185-194. [CrossRef] [PubMed]

66. Jin, Y.; Feng, S.-J.; Qiu, S.; Shao, N.; Zheng, J.-H. LncRNA MALAT1 Promotes Proliferation and Metastasis in Epithelial Ovarian Cancer via the PI3K-AKT Pathway. Eur. Rev. Med. Pharmacol. Sci. 2017, 21, 3176-3184. [PubMed]

67. Liang, H.; Zhao, X.; Wang, C.; Sun, J.; Chen, Y.; Wang, G.; Fang, L.; Yang, R.; Yu, M.; Gu, Y.; et al. Systematic Analyses Reveal Long Non-Coding RNA (PTAF)-Mediated Promotion of EMT and Invasion-Metastasis in Serous Ovarian Cancer. Mol. Cancer 2018, 17, 96. [CrossRef]

68. Katz, B.; Tropé, C.G.; Reich, R.; Davidson, B. MicroRNAs in Ovarian Cancer. Hum. Pathol. 2015, 46, 1245-1256. [CrossRef] [PubMed]

69. Deb, B.; Uddin, A.; Chakraborty, S. MiRNAs and Ovarian Cancer: An Overview. J. Cell. Physiol. 2018, 233, 3846-3854. [CrossRef]

70. Pei, Y.; Li, K.; Lou, X.; Wu, Y.; Dong, X.; Wang, W.; Li, N.; Zhang, D.; Cui, W. MiR-1299/NOTCH3/TUG1 Feedback Loop Contributes to the Malignant Proliferation of Ovarian Cancer. Oncol. Rep. 2020, 44, 438-448. [CrossRef]

71. Peng, Y.; Croce, C.M. The Role of MicroRNAs in Human Cancer. Signal Transduct. Target. Ther. 2016, 1, 15004. [CrossRef]

72. Le, M.T.N.; Teh, C.; Shyh-Chang, N.; Xie, H.; Zhou, B.; Korzh, V.; Lodish, H.F.; Lim, B. MicroRNA-125b Is a Novel Negative Regulator of P53. Genes Dev. 2009, 23, 862-876. [CrossRef] [PubMed]

73. Vaksman, O.; Stavnes, H.T.; Kaern, J.; Trope, C.G.; Davidson, B.; Reich, R. MiRNA Profiling along Tumour Progression in Ovarian Carcinoma. J. Cell. Mol. Med. 2011, 15, 1593-1602. [CrossRef]

74. Koutsaki, M.; Libra, M.; Spandidos, D.A.; Zaravinos, A. The MiR-200 Family in Ovarian Cancer. Oncotarget 2017, 8, 66629-66640. [CrossRef] [PubMed]

75. Suo, H.-B.; Zhang, K.-C.; Zhao, J. MiR-200a Promotes Cell Invasion and Migration of Ovarian Carcinoma by Targeting PTEN. Eur. Rev. Med. Pharmacol. Sci. 2018, 22, 4080-4089. [CrossRef] [PubMed]

76. Yang, D.; Sun, Y.; Hu, L.; Zheng, H.; Ji, P.; Pecot, C.V.; Zhao, Y.; Reynolds, S.; Cheng, H.; Rupaimoole, R.; et al. Integrated Analyses Identify a Master MicroRNA Regulatory Network for the Mesenchymal Subtype in Serous Ovarian Cancer. Cancer Cell 2013, 23, 186-199. [CrossRef]

77. Duan, Y.; Dong, Y.; Dang, R.; Hu, Z.; Yang, Y.; Hu, Y.; Cheng, J. MiR-122 Inhibits Epithelial Mesenchymal Transition by Regulating P4HA1 in Ovarian Cancer Cells. Cell Biol. Int. 2018, 42, 1564-1574. [CrossRef] [PubMed]

78. Vang, S.; Wu, H.-T.; Fischer, A.; Miller, D.H.; MacLaughlan, S.; Douglass, E.; Comisar, L.; Steinhoff, M.; Collins, C.; Smith, P.J.S.; et al. Identification of Ovarian Cancer Metastatic MiRNAs. PLoS ONE 2013, 8, e58226. [CrossRef]

79. Bachmayr-Heyda, A.; Auer, K.; Sukhbaatar, N.; Aust, S.; Deycmar, S.; Reiner, A.T.; Polterauer, S.; Dekan, S.; Pils, D. Small RNAs and the Competing Endogenous RNA Network in High Grade Serous Ovarian Cancer Tumor Spread. Oncotarget 2016, 7, 39640-39653. [CrossRef]

80. Salem, M.; O’Brien, J.A.; Bernaudo, S.; Shawer, H.; Ye, G.; Brkić, J.; Amleh, A.; Vanderhyden, B.C.; Refky, B.; Yang, B.B.; et al. MiR-590-3p Promotes Ovarian Cancer Growth and Metastasis via a Novel FOXA2-Versican Pathway. Cancer Res. 2018, 78, 4175-4190. [CrossRef]

81. Zuberi, M.; Mir, R.; Khan, I.; Javid, J.; Guru, S.A.; Bhat, M.; Sumi, M.P.; Ahmad, I.; Masroor, M.; Yadav, P.; et al. The Promising Signatures of Circulating MicroRNA-145 in Epithelial Ovarian Cancer Patients. MicroRNA 2020, 9, 49-57. [CrossRef]

82. Zuberi, M.; Khan, I.; Mir, R.; Gandhi, G.; Ray, P.C.; Saxena, A. Utility of Serum MiR-125b as a Diagnostic and Prognostic Indicator and Its Alliance with a Panel of Tumor Suppressor Genes in Epithelial Ovarian Cancer. PLoS ONE 2016, 11, e0153902. [CrossRef]

83. Wynendaele, J.; Böhnke, A.; Leucci, E.; Nielsen, S.J.; Lambertz, I.; Hammer, S.; Sbrzesny, N.; Kubitza, D.; Wolf, A.; Gradhand, E.; et al. An Illegitimate MicroRNA Target Site within the 3' UTR of MDM4 Affects Ovarian Cancer Progression and Chemosensitivity. Cancer Res. 2010, 70, 9641-9649. [CrossRef]

84. Song, Z.-S.; Wu, Y.; Zhao, H.-G.; Liu, C.-X.; Cai, H.-Y.; Guo, B.-Z.; Xie, Y.A.; Shi, H.-R. Association between the Rs11614913 Variant of MiRNA-196a-2 and the Risk of Epithelial Ovarian Cancer. Oncol. Lett. 2016, 11, 194-200. [CrossRef]

85. Permuth-Wey, J.; Chen, Z.; Tsai, Y.-Y.; Lin, H.-Y.; Chen, Y.A.; Barnholtz-Sloan, J.; Birrer, M.J.; Chanock, S.J.; Cramer, D.W.; Cunningham, J.M.; et al. MicroRNA Processing and Binding Site Polymorphisms Are Not Replicated in the Ovarian Cancer Association Consortium. Cancer Epidemiol. Prev. Biomark. 2011, 20, 1793-1797. [CrossRef] [PubMed]

86. Li, J.; Shao, W.; Feng, H. MiR-542-3p, a MicroRNA Targeting CDK14, Suppresses Cell Proliferation, Invasiveness, and Tumorigenesis of Epithelial Ovarian Cancer. Biomed. Pharmacother. 2019, 110, 850-856. [CrossRef] [PubMed]

87. Xing, F.; Song, Z.; He, Y. MiR-219-5p Inhibits Growth and Metastasis of Ovarian Cancer Cells by Targeting HMGA2. Biol. Res. 2018, 51, 50. [CrossRef] [PubMed] 
88. Bai, L.; Wang, H.; Wang, A.-H.; Zhang, L.-Y.; Bai, J. MicroRNA-532 and MicroRNA-3064 Inhibit Cell Proliferation and Invasion by Acting as Direct Regulators of Human Telomerase Reverse Transcriptase in Ovarian Cancer. PLoS ONE 2017, 12, 0173912. [CrossRef]

89. Gong, L.; Zhang, W.; Yuan, Y.; Xing, X.; Li, H.; Zhao, G. MiR-222 Promotes Invasion and Migration of Ovarian Carcinoma by Targeting PTEN. Oncol. Lett. 2018, 16, 984-990. [CrossRef]

90. Li, J.; Hu, K.; Gong, G.; Zhu, D.; Wang, Y.; Liu, H.; Wu, X. Upregulation of MiR-205 Transcriptionally Suppresses SMAD4 and PTEN and Contributes to Human Ovarian Cancer Progression. Sci. Rep. 2017, 7, 41330. [CrossRef]

91. Yang, L.; Wei, Q.-M.; Zhang, X.-W.; Sheng, Q.; Yan, X.-T. MiR-376a Promotion of Proliferation and Metastases in Ovarian Cancer: Potential Role as a Biomarker. Life Sci. 2017, 173, 62-67. [CrossRef]

92. Chen, L.; Zhang, F.; Sheng, X.; Zhang, S.; Chen, Y.; Liu, B. MicroRNA-106a Regulates Phosphatase and Tensin Homologue Expression and Promotes the Proliferation and Invasion of Ovarian Cancer Cells. Oncol. Rep. 2016, 36, 2135-2141. [CrossRef] [PubMed]

93. Dong, R.; Liu, X.; Zhang, Q.; Jiang, Z.; Li, Y.; Wei, Y.; Li, Y.; Yang, Q.; Liu, J.; Wei, J.-J.; et al. MiR-145 Inhibits Tumor Growth and Metastasis by Targeting Metadherin in High-Grade Serous Ovarian Carcinoma. Oncotarget 2014, 5, 10816-10829. [CrossRef] [PubMed]

94. Guo, L.-M.; Pu, Y.; Han, Z.; Liu, T.; Li, Y.-X.; Liu, M.; Li, X.; Tang, H. MicroRNA-9 Inhibits Ovarian Cancer Cell Growth through Regulation of NF-KappaB1. FEBS J. 2009, 276, 5537-5546. [CrossRef] [PubMed]

95. Li, W.; Liu, Z.; Chen, L.; Zhou, L.; Yao, Y. MicroRNA-23b Is an Independent Prognostic Marker and Suppresses Ovarian Cancer Progression by Targeting Runt-Related Transcription Factor-2. FEBS Lett. 2014, 588, 1608-1615. [CrossRef] [PubMed]

96. Chen, S.; Chen, X.; Xiu, Y.-L.; Sun, K.-X.; Zhao, Y. Inhibition of Ovarian Epithelial Carcinoma Tumorigenesis and Progression by MicroRNA 106b Mediated through the RhoC Pathway. PLoS ONE 2015, 10, e0125714. [CrossRef]

97. Yeh, Y.-M.; Chuang, C.-M.; Chao, K.-C.; Wang, L.-H. MicroRNA-138 Suppresses Ovarian Cancer Cell Invasion and Metastasis by Targeting SOX4 and HIF-1 $\alpha$. Int. J. Cancer 2013, 133, 867-878. [CrossRef] [PubMed]

98. Mak, C.S.L.; Yung, M.M.H.; Hui, L.M.N.; Leung, L.L.; Liang, R.; Chen, K.; Liu, S.S.; Qin, Y.; Leung, T.H.Y.; Lee, K.-F.; et al. MicroRNA-141 Enhances Anoikis Resistance in Metastatic Progression of Ovarian Cancer through Targeting KLF12/Sp1/Survivin Axis. Mol. Cancer 2017, 16, 11. [CrossRef] [PubMed]

99. Liu, X.; Yao, B.; Wu, Z. MiRNA-199a-5p Suppresses Proliferation and Invasion by Directly Targeting NF-KB1 in Human Ovarian Cancer Cells. Oncol. Lett. 2018, 16, 4543-4550. [CrossRef]

100. Yang, C.; Li, H.; Zhang, T.; Chu, Y.; Chen, D.; Zuo, J. MiR-200c Overexpression Inhibits the Invasion and Tumorigenicity of Epithelial Ovarian Cancer Cells by Suppressing LncRNA HOTAIR in Mice. J. Cell. Biochem. 2020, 121, 1514-1523. [CrossRef]

101. Imam, J.S.; Plyler, J.R.; Bansal, H.; Prajapati, S.; Bansal, S.; Rebeles, J.; Chen, H.-I.H.; Chang, Y.-F.; Panneerdoss, S.; Zoghi, B.; et al. Genomic Loss of Tumor Suppressor MiRNA-204 Promotes Cancer Cell Migration and Invasion by Activating AKT/MTOR/Rac1 Signaling and Actin Reorganization. PLoS ONE 2012, 7, e52397. [CrossRef]

102. Zhang, Z.; Zhang, L.; Wang, B.; Wei, R.; Wang, Y.; Wan, J.; Zhang, C.; Zhao, L.; Zhu, X.; Zhang, Y.; et al. MiR-337-3p Suppresses Proliferation of Epithelial Ovarian Cancer by Targeting PIK3CA and PIK3CB. Cancer Lett. 2020, 469, 54-67. [CrossRef]

103. Leng, R.; Zha, L.; Tang, L. MiR-718 Represses VEGF and Inhibits Ovarian Cancer Cell Progression. FEBS Lett. 2014, 588, 2078-2086. [CrossRef]

104. Ebrahimi, S.O.; Reiisi, S. Downregulation of MiR-4443 and MiR-5195-3p in Ovarian Cancer Tissue Contributes to Metastasis and Tumorigenesis. Arch. Gynecol. Obstet. 2019, 299, 1453-1458. [CrossRef] [PubMed]

105. Schmitt, A.M.; Chang, H.Y. Long Noncoding RNAs in Cancer Pathways. Cancer Cell 2016, 29, 452-463. [CrossRef] [PubMed]

106. Fang, Y.; Fullwood, M.J. Roles, Functions, and Mechanisms of Long Non-Coding RNAs in Cancer. Genom. Proteom. Bioinform. 2016, 14, 42-54. [CrossRef] [PubMed]

107. Morlando, M.; Fatica, A. Alteration of Epigenetic Regulation by Long Noncoding RNAs in Cancer. Int. J. Mol. Sci. 2018, 19, 570. [CrossRef]

108. Marchese, F.P.; Raimondi, I.; Huarte, M. The Multidimensional Mechanisms of Long Noncoding RNA Function. Genome Biol. 2017, 18, 206. [CrossRef] [PubMed]

109. Rinn, J.L.; Chang, H.Y. Genome Regulation by Long Noncoding RNAs. Annu. Rev. Biochem. 2012, 81, 145-166. [CrossRef] [PubMed]

110. Sun, B.; Liu, C.; Li, H.; Zhang, L.; Luo, G.; Liang, S.; Lü, M. Research Progress on the Interactions between Long Non-coding RNAs and MicroRNAs in Human Cancer (Review). Oncol. Lett. 2020, 19, 595-605. [CrossRef] [PubMed]

111. Zhu, L.; Guo, Q.; Lu, X.; Zhao, J.; Shi, J.; Wang, Z.; Zhou, X. CTD-2020K17.1, a Novel Long Non-Coding RNA, Promotes Migration, Invasion, and Proliferation of Serous Ovarian Cancer Cells In Vitro. Med. Sci. Monit. Int. Med. J. Exp. Clin. Res. 2018, 24, 1329-1339. [CrossRef]

112. Zhang, Y.; Ruan, F. LncRNA LEF1-AS1 Promotes Ovarian Cancer Development Through Interacting with MiR-1285-3p. Cancer Manag. Res. 2020, 12, 687-694. [CrossRef]

113. Xiu, Y.-L.; Sun, K.-X.; Chen, X.; Chen, S.; Zhao, Y.; Guo, Q.-G.; Zong, Z.-H. Upregulation of the LncRNA Meg3 Induces Autophagy to Inhibit Tumorigenesis and Progression of Epithelial Ovarian Carcinoma by Regulating Activity of ATG3. Oncotarget 2017, 8 , 31714-31725. [CrossRef] [PubMed] 
114. Liu, S.-P.; Yang, J.-X.; Cao, D.-Y.; Shen, K. Identification of Differentially Expressed Long Non-Coding RNAs in Human Ovarian Cancer Cells with Different Metastatic Potentials. Cancer Biol. Med. 2013, 10, 138-141. [CrossRef] [PubMed]

115. Guo, Q.; Cheng, Y.; Liang, T.; He, Y.; Ren, C.; Sun, L.; Zhang, G. Comprehensive Analysis of LncRNA-MRNA Co-Expression Patterns Identifies Immune-Associated LncRNA Biomarkers in Ovarian Cancer Malignant Progression. Sci. Rep. 2015,5 , 17683. [CrossRef]

116. Chen, Q.; Su, Y.; He, X.; Zhao, W.; Wu, C.; Zhang, W.; Si, X.; Dong, B.; Zhao, L.; Gao, Y.; et al. Plasma Long Non-Coding RNA MALAT1 Is Associated with Distant Metastasis in Patients with Epithelial Ovarian Cancer. Oncol. Lett. 2016, 12, 1361-1366. [CrossRef]

117. Zhang, H.; Yao, B.; Tang, S.; Chen, Y. LINK-A Long Non-Coding RNA (LncRNA) Participates in Metastasis of Ovarian Carcinoma and Upregulates Hypoxia-Inducible Factor 1 (HIF1 $\alpha$ ). Med. Sci. Monit. Int. Med. J. Exp. Clin. Res. 2019, 25, 2221-2227. [CrossRef]

118. Ma, J.; Xue, M. LINK-A LncRNA Promotes Migration and Invasion of Ovarian Carcinoma Cells by Activating TGF- $\beta$ Pathway. Biosci. Rep. 2018, 38, BSR20180936. [CrossRef] [PubMed]

119. Non-Coding RNA in the Exosome of the Epithelial Ovarian Cancer. Available online: https://clinicaltrials.gov/ct2/show/NCT0 3738319 (accessed on 4 August 2020).

120. Reid, B.M.; Permuth, J.B.; Chen, Y.A.; Teer, J.K.; Monteiro, A.N.A.; Chen, Z.; Tyrer, J.; Berchuck, A.; Chenevix-Trench, G.; Doherty, J.A.; et al. Integration of Population-Level Genotype Data with Functional Annotation Reveals over-Representation of Long Non-Coding RNAs at Ovarian Cancer Susceptibility Loci. Cancer Epidemiol. Prev. Biomark. 2017, 26, 116-125. [CrossRef]

121. Richards, E.J.; Permuth-Wey, J.; Li, Y.; Chen, Y.A.; Coppola, D.; Reid, B.M.; Lin, H.-Y.; Teer, J.K.; Berchuck, A.; Birrer, M.J.; et al. A Functional Variant in HOXA11-AS, a Novel Long Non-Coding RNA, Inhibits the Oncogenic Phenotype of Epithelial Ovarian Cancer. Oncotarget 2015, 6, 34745-34757. [CrossRef] [PubMed]

122. Qiu, H.; Wang, X.; Guo, R.; Liu, Q.; Wang, Y.; Yuan, Z.; Li, J.; Shi, H. HOTAIR Rs920778 Polymorphism Is Associated with Ovarian Cancer Susceptibility and Poor Prognosis in a Chinese Population. Future Oncol. Lond. Engl. 2017, 13, 347-355. [CrossRef]

123. Wu, H.; Shang, X.; Shi, Y.; Yang, Z.; Zhao, J.; Yang, M.; Li, Y.; Xu, S. Genetic Variants of LncRNA HOTAIR and Risk of Epithelial Ovarian Cancer among Chinese Women. Oncotarget 2016, 7, 41047-41052. [CrossRef] [PubMed]

124. Wang, X.; Yang, B.; She, Y.; Ye, Y. The LncRNA TP73-AS1 Promotes Ovarian Cancer Cell Proliferation and Metastasis via Modulation of MMP2 and MMP9. J. Cell. Biochem. 2018, 119, 7790-7799. [CrossRef] [PubMed]

125. Qiu, J.-J.; Lin, Y.-Y.; Ding, J.-X.; Feng, W.-W.; Jin, H.-Y.; Hua, K.-Q. Long Non-Coding RNA ANRIL Predicts Poor Prognosis and Promotes Invasion/Metastasis in Serous Ovarian Cancer. Int. J. Oncol. 2015, 46, 2497-2505. [CrossRef]

126. Yang, Y.; Jiang, Y.; Wan, Y.; Zhang, L.; Qiu, J.; Zhou, S.; Cheng, W. UCA1 Functions as a Competing Endogenous RNA to Suppress Epithelial Ovarian Cancer Metastasis. Tumour Biol. J. Int. Soc. Oncodev. Biol. Med. 2016, 37, 10633-10641. [CrossRef] [PubMed]

127. Liang, H.; Yu, T.; Han, Y.; Jiang, H.; Wang, C.; You, T.; Zhao, X.; Shan, H.; Yang, R.; Yang, L.; et al. LncRNA PTAR Promotes EMT and Invasion-Metastasis in Serous Ovarian Cancer by Competitively Binding MiR-101-3p to Regulate ZEB1 Expression. Mol. Cancer 2018, 17, 119. [CrossRef] [PubMed]

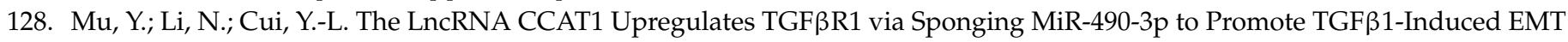
of Ovarian Cancer Cells. Cancer Cell Int. 2018, 18, 145. [CrossRef]

129. Lai, X.-J.; Cheng, H.-F. LncRNA Colon Cancer-Associated Transcript 1 (CCAT1) Promotes Proliferation and Metastasis of Ovarian Cancer via MiR-1290. Eur. Rev. Med. Pharmacol. Sci. 2018, 22, 322-328. [CrossRef]

130. Lei, R.; Xue, M.; Zhang, L.; Lin, Z. Long Noncoding RNA MALAT1-Regulated MicroRNA 506 Modulates Ovarian Cancer Growth by Targeting IASPP. OncoTargets Ther. 2016, 10, 35-46. [CrossRef]

131. Yong, W.; Yu, D.; Jun, Z.; Yachen, D.; Weiwei, W.; Midie, X.; Xingzhu, J.; Xiaohua, W. Long Noncoding RNA NEAT1, Regulated by LIN28B, Promotes Cell Proliferation and Migration through Sponging MiR-506 in High-Grade Serous Ovarian Cancer. Cell Death Dis. 2018, 9, 861. [CrossRef]

132. Yan, H.; Silva, M.A.; Li, H.; Zhu, L.; Li, P.; Li, X.; Wang, X.; Gao, J.; Wang, P.; Zhang, Z. Long Noncoding RNA DQ786243 Interacts with MiR-506 and Promotes Progression of Ovarian Cancer through Targeting CAMP Responsive Element Binding Protein 1. J. Cell. Biochem. 2018, 119, 9764-9780. [CrossRef]

133. He, S.; Zhao, Y.; Wang, X.; Deng, Y.; Wan, Z.; Yao, S.; Shen, H. Up-Regulation of Long Non-Coding RNA SNHG20 Promotes Ovarian Cancer Progression via Wnt/ $\beta$-Catenin Signaling. Biosci. Rep. 2018, 38, BSR20170681. [CrossRef] [PubMed]

134. Guo, C.; Wang, X.; Chen, L.-P.; Li, M.; Li, M.; Hu, Y.-H.; Ding, W.-H.; Wang, X. Long Non-Coding RNA MALAT1 Regulates Ovarian Cancer Cell Proliferation, Migration and Apoptosis through Wnt/ $\beta$-Catenin Signaling Pathway. Eur. Rev. Med. Pharmacol. Sci. 2018, 22, 3703-3712. [CrossRef]

135. Zhang, Y.; Dun, Y.; Zhou, S.; Huang, X.-H. LncRNA HOXD-AS1 Promotes Epithelial Ovarian Cancer Cells Proliferation and Invasion by Targeting MiR-133a-3p and Activating Wnt/ $\beta$-Catenin Signaling Pathway. Biomed. Pharmacother. 2017, 96, 1216-1221. [CrossRef] [PubMed]

136. Lou, Y.; Jiang, H.; Cui, Z.; Wang, L.; Wang, X.; Tian, T. Linc-ROR Induces Epithelial-to-Mesenchymal Transition in Ovarian Cancer by Increasing Wnt/ $\beta$-Catenin Signaling. Oncotarget 2017, 8, 69983-69994. [CrossRef] [PubMed]

137. Li, J.; Yang, S.; Su, N.; Wang, Y.; Yu, J.; Qiu, H.; He, X. Overexpression of Long Non-Coding RNA HOTAIR Leads to Chemoresistance by Activating the Wnt/ $\beta$-Catenin Pathway in Human Ovarian Cancer. Tumour Biol. J. Int. Soc. Oncodev. Biol. Med. 2016, 37, 2057-2065. [CrossRef] [PubMed] 
138. Li, J.; Feng, L.; Tian, C.; Tang, Y.-L.; Tang, Y.; Hu, F.-Q. Long Noncoding RNA-JPX Predicts the Poor Prognosis of Ovarian Cancer Patients and Promotes Tumor Cell Proliferation, Invasion and Migration by the PI3K/Akt/MTOR Signaling Pathway. Eur. Rev. Med. Pharmacol. Sci. 2018, 22, 8135-8144. [CrossRef]

139. Benetatos, L.; Vartholomatos, G.; Hatzimichael, E. MEG3 Imprinted Gene Contribution in Tumorigenesis. Int. J. Cancer 2011, 129, 773-779. [CrossRef] [PubMed]

140. Wang, A.; Jin, C.; Li, H.; Qin, Q.; Li, L. LncRNA ADAMTS9-AS2 Regulates Ovarian Cancer Progression by Targeting MiR-1825p/FOXF2 Signaling Pathway. Int. J. Biol. Macromol. 2018, 120, 1705-1713. [CrossRef]

141. Qiu, J.-J.; Wang, Y.; Liu, Y.-L.; Zhang, Y.; Ding, J.-X.; Hua, K.-Q. The Long Non-Coding RNA ANRIL Promotes Proliferation and Cell Cycle Progression and Inhibits Apoptosis and Senescence in Epithelial Ovarian Cancer. Oncotarget 2016, 7, 32478-32492. [CrossRef]

142. Lin, X.; Tang, X.; Zheng, T.; Qiu, J.; Hua, K. Long Non-Coding RNA AOC4P Suppresses Epithelial Ovarian Cancer Metastasis by Regulating Epithelial-Mesenchymal Transition. J. Ovarian Res. 2020, 13, 45. [CrossRef]

143. Fu, Y.; Biglia, N.; Wang, Z.; Shen, Y.; Risch, H.A.; Lu, L.; Canuto, E.M.; Jia, W.; Katsaros, D.; Yu, H. Long Non-Coding RNAs, ASAP1-IT1, FAM215A, and LINC00472, in Epithelial Ovarian Cancer. Gynecol. Oncol. 2016, 143, 642-649. [CrossRef]

144. Yang, H.; Qi, Y.; Wang, X.; Gu, J.; Shi, T. Down-Regulation of LncRNA BLACAT1 Inhibits Ovarian Cancer Progression by Suppressing the Wnt/ $\beta$-Catenin Signaling Pathway via Regulating MiR-519d-3p. Mol. Cell. Biochem. 2020, 467, 95-105. [CrossRef]

145. Hu, X.; Li, Y.; Kong, D.; Hu, L.; Liu, D.; Wu, J. Long Noncoding RNA CASC9 Promotes LIN7A Expression via MiR-758-3p to Facilitate the Malignancy of Ovarian Cancer. J. Cell. Physiol. 2019, 234, 10800-10808. [CrossRef]

146. Huang, S.; Qing, C.; Huang, Z.; Zhu, Y. The Long Non-Coding RNA CCAT2 Is up-Regulated in Ovarian Cancer and Associated with Poor Prognosis. Diagn. Pathol. 2016, 11, 49. [CrossRef]

147. Wang, H.-M.; Shen, S.-L.; Li, N.-M.; Su, H.-F.; Li, W.-Y. LncRNA CDKN2BAS Aggravates the Progression of Ovarian Cancer by Positively Interacting with GAS6. Eur. Rev. Med. Pharmacol. Sci. 2020, 24, 5946-5952. [CrossRef]

148. Lin, X.; Yang, F.; Qi, X.; Li, Q.; Wang, D.; Yi, T.; Yin, R.; Zhao, X.; Zhong, X.; Bian, C. LncRNA DANCR Promotes Tumor Growth and Angiogenesis in Ovarian Cancer through Direct Targeting of MiR-145. Mol. Carcinog. 2019, 58, 2286-2296. [CrossRef] [PubMed]

149. Mitra, R.; Chen, X.; Greenawalt, E.J.; Maulik, U.; Jiang, W.; Zhao, Z.; Eischen, C.M. Decoding Critical Long Non-Coding RNA in Ovarian Cancer Epithelial-to-Mesenchymal Transition. Nat. Commun. 2017, 8, 1604. [CrossRef] [PubMed]

150. You, Q.; Yao, Y.; Wu, J.; Cheng, C.; Li, Y.; Yuan, H. YY1-Induced LncRNA DSCR8 Promotes the Progression of Ovarian Cancer via MiR-3192-5p/YY1 Axis. Biomed. Pharmacother. 2020, 129, 110339. [CrossRef] [PubMed]

151. Xu, Q.-F.; Tang, Y.-X.; Wang, X. LncRNA EBIC Promoted Proliferation, Metastasis and Cisplatin Resistance of Ovarian Cancer Cells and Predicted Poor Survival in Ovarian Cancer Patients. Eur. Rev. Med. Pharmacol. Sci. 2018, 22, 4440-4447. [CrossRef]

152. Sun, T.; Yang, P.; Gao, Y. Long Non-Coding RNA EPB41L4A-AS2 Suppresses Progression of Ovarian Cancer by Sequestering MicroRNA-103a to Upregulate Transcription Factor RUNX1T1. Exp. Physiol. 2020, 105, 75-87. [CrossRef] [PubMed]

153. Zhang, Q.; Len, T.-Y.; Zhang, S.-X.; Zhao, Q.-H.; Yang, L.-H. Exosomes Transferring Long Non-Coding RNA FAL1 to Regulate Ovarian Cancer Metastasis through the PTEN/AKT Signaling Pathway. Eur. Rev. Med. Pharmacol. Sci. 2020, 24, 43-54. [CrossRef]

154. Gong, Y.-B.; Zou, Y.-F. Clinical Significance of LncRNA FAM83H-AS1 in Ovarian Cancer. Eur. Rev. Med. Pharmacol. Sci. 2019, 23, 4656-4662. [CrossRef] [PubMed]

155. Dou, Q.; Xu, Y.; Zhu, Y.; Hu, Y.; Yan, Y.; Yan, H. LncRNA FAM83H-AS1 Contributes to the Radioresistance, Proliferation, and Metastasis in Ovarian Cancer through Stabilizing HuR Protein. Eur. J. Pharmacol. 2019, 852, 134-141. [CrossRef] [PubMed]

156. Sun, Z.; Gao, S.; Xuan, L.; Liu, X. Long Non-Coding RNA FEZF1-AS1 Induced Progression of Ovarian Cancer via Regulating MiR-130a-5p/SOX4 Axis. J. Cell. Mol. Med. 2020, 24, 4275-4285. [CrossRef] [PubMed]

157. Yan, H.; Li, H.; Silva, M.A.; Guan, Y.; Yang, L.; Zhu, L.; Zhang, Z.; Li, G.; Ren, C. LncRNA FLVCR1-AS1 Mediates MiR-513/YAP1 Signaling to Promote Cell Progression, Migration, Invasion and EMT Process in Ovarian Cancer. J. Exp. Clin. Cancer Res. 2019, 38, 356. [CrossRef]

158. Li, J.; Huang, Y.; Deng, X.; Luo, M.; Wang, X.; Hu, H.; Liu, C.; Zhong, M. Long Noncoding RNA H19 Promotes Transforming Growth Factor- $\beta$-Induced Epithelial-Mesenchymal Transition by Acting as a Competing Endogenous RNA of MiR-370-3p in Ovarian Cancer Cells. OncoTargets Ther. 2018, 11, 427-440. [CrossRef]

159. Wu, K.; Li, L.; Li, L.; Wang, D. Long Non-Coding RNA HAL Suppresses the Migration and Invasion of Serous Ovarian Cancer by Inhibiting EMT Signaling Pathway. Biosci. Rep. 2020, 40, BSR20194496. [CrossRef] [PubMed]

160. Gokulnath, P.; de Cristofaro, T.; Manipur, I.; Di Palma, T.; Soriano, A.A.; Guarracino, M.R.; Zannini, M. Long Non-Coding RNA HAND2-AS1 Acts as a Tumor Suppressor in High-Grade Serous Ovarian Carcinoma. Int. J. Mol. Sci. 2020, 21, 4059. [CrossRef]

161. Wang, L.; He, M.; Fu, L.; Jin, Y. Role of LncRNAHCP5/MicroRNA-525-5p/PRC1 Crosstalk in the Malignant Behaviors of Ovarian Cancer Cells. Exp. Cell Res. 2020, 394, 112129. [CrossRef]

162. Dong, L.; Hu, L. HOTAIR Promotes Proliferation, Migration, and Invasion of Ovarian Cancer SKOV3 Cells Through Regulating PIK3R3. Med. Sci. Monit. Int. Med. J. Exp. Clin. Res. 2016, 22, 325-331. [CrossRef]

163. Qiu, J.; Lin, Y.; Ye, L.; Ding, J.; Feng, W.; Jin, H.; Zhang, Y.; Li, Q.; Hua, K. Overexpression of Long Non-Coding RNA HOTAIR Predicts Poor Patient Prognosis and Promotes Tumor Metastasis in Epithelial Ovarian Cancer. Gynecol. Oncol. 2014, 134, 121-128. [CrossRef] 
164. Chao, H.; Zhang, M.; Hou, H.; Zhang, Z.; Li, N. HOTAIRM1 Suppresses Cell Proliferation and Invasion in Ovarian Cancer through Facilitating ARHGAP24 Expression by Sponging MiR-106a-5p. Life Sci. 2020, 243, 117296. [CrossRef]

165. Zou, T.; Wang, P.L.; Gao, Y.; Liang, W.T. Long Noncoding RNA HOTTIP Is a Significant Indicator of Ovarian Cancer Prognosis and Enhances Cell Proliferation and Invasion. Cancer Biomark. Sect. Dis. Markers 2019, 25, 133-139. [CrossRef]

166. Dong, S.; Wang, R.; Wang, H.; Ding, Q.; Zhou, X.; Wang, J.; Zhang, K.; Long, Y.; Lu, S.; Hong, T.; et al. HOXD-AS1 Promotes the Epithelial to Mesenchymal Transition of Ovarian Cancer Cells by Regulating MiR-186-5p and PIK3R3. J. Exp. Clin. Cancer Res. 2019, 38, 110. [CrossRef]

167. Liu, H.; Chen, R.; Kang, F.; Lai, H.; Wang, Y. KCNQ1OT1 Promotes Ovarian Cancer Progression via Modulating MIR-1425p/CAPN10 Axis. Mol. Genet. Genom. Med. 2020, 8, e1077. [CrossRef]

168. Lu, X.; Wang, F.; Fu, M.; Li, Y.; Wang, L. Long Noncoding RNA KCNQ1OT1 Accelerates the Progression of Ovarian Cancer via MicroRNA-212-3/LCN2 Axis. Oncol. Res. 2020, 28, 135-146. [CrossRef]

169. Zhao, L.; Ji, G.; Le, X.; Wang, C.; Xu, L.; Feng, M.; Zhang, Y.; Yang, H.; Xuan, Y.; Yang, Y.; et al. Long Noncoding RNA LINC00092 Acts in Cancer-Associated Fibroblasts to Drive Glycolysis and Progression of Ovarian Cancer. Cancer Res. 2017, 77, 1369-1382. [CrossRef] [PubMed]

170. Dai, L.; Niu, J.; Feng, Y. Knockdown of Long Non-Coding RNA LINC00176 Suppresses Ovarian Cancer Progression by BCL3Mediated down-Regulation of Ceruloplasmin. J. Cell. Mol. Med. 2020, 24, 202-213. [CrossRef] [PubMed]

171. Pan, L.; Meng, Q.; Li, H.; Liang, K.; Li, B. LINC00339 Promotes Cell Proliferation, Migration, and Invasion of Ovarian Cancer Cells via MiR-148a-3p/ROCK1 Axes. Biomed. Pharmacother. 2019, 120, 109423. [CrossRef] [PubMed]

172. Liu, X.; Wen, J.; Wang, H.; Wang, Y. Long Non-Coding RNA LINC00460 Promotes Epithelial Ovarian Cancer Progression by Regulating MicroRNA-338-3p. Biomed. Pharmacother. 2018, 108, 1022-1028. [CrossRef]

173. Liu, Y.; He, X.; Chen, Y.; Cao, D. Long Non-Coding RNA LINC00504 Regulates the Warburg Effect in Ovarian Cancer through Inhibition of MiR-1244. Mol. Cell. Biochem. 2020, 464, 39-50. [CrossRef]

174. Gong, M.; Luo, C.; Meng, H.; Li, S.; Nie, S.; Jiang, Y.; Wan, Y.; Li, H.; Cheng, W. Upregulated LINC00565 Accelerates Ovarian Cancer Progression By Targeting GAS6. OncoTargets Ther. 2019, 12, 10011-10022. [CrossRef]

175. Liu, W.; Yang, Y.-J.; An, Q. LINC00963 Promotes Ovarian Cancer Proliferation, Migration and EMT via the MiR-378g /CHI3L1 Axis. Cancer Manag. Res. 2020, 12, 463-473. [CrossRef]

176. Yuan, D.; Qian, H.; Guo, T.; Ye, J.; Jin, C.; Liu, X.; Jiang, L.; Wang, X.; Lin, M.; Yu, H. LncRNA-ATB Promotes the Tumorigenesis of Ovarian Cancer via Targeting MiR-204-3p. OncoTargets Ther. 2020, 13, 573-583. [CrossRef]

177. Yuan, D.; Zhang, X.; Zhao, Y.; Qian, H.; Wang, H.; He, C.; Liu, X.; Guo, T.; Lin, M.; Yu, H.; et al. Role of LncRNA-ATB in Ovarian Cancer and Its Mechanisms of Action. Exp. Ther. Med. 2020, 19, 965-971. [CrossRef] [PubMed]

178. Liu, Y.; Wang, Y.; Yao, D.; Cui, D. LncSOX4 Serves an Oncogenic Role in the Tumorigenesis of Epithelial Ovarian Cancer by Promoting Cell Proliferation and Inhibiting Apoptosis. Mol. Med. Rep. 2018, 17, 8282-8288. [CrossRef]

179. Tao, F.; Tian, X.; Lu, M.; Zhang, Z. A Novel LncRNA, Lnc-OC1, Promotes Ovarian Cancer Cell Proliferation and Migration by Sponging MiR-34a and MiR-34c. J. Genet. Genom. Yi Chuan Xue Bao 2018, 45, 137-145. [CrossRef] [PubMed]

180. Xue, F.; Xu, Y.H.; Shen, C.C.; Qin, Z.L.; Zhou, H.B. Non-Coding RNA LOXL1-AS1 Exhibits Oncogenic Activity in Ovarian Cancer via Regulation of MiR-18b-5p/VMA21 Axis. Biomed. Pharmacother. 2020, 125, 109568. [CrossRef]

181. Liu, H.-Z.; Liu, G.-Y.; Pang, W.-W.; Zhang, H.; Zeng, Z.-J.; Wang, H.-J. LncRNA LUCAT1 Promotes Proliferation of Ovarian Cancer Cells by Regulating MiR-199a-5p Expression. Eur. Rev. Med. Pharmacol. Sci. 2020, 24, 1682-1687. [CrossRef] [PubMed]

182. Wu, X.; Wang, Y.; Zhong, W.; Cheng, H.; Tian, Z. The Long Non-Coding RNA MALAT1 Enhances Ovarian Cancer Cell Stemness by Inhibiting YAP Translocation from Nucleus to Cytoplasm. Med. Sci. Monit. Int. Med. J. Exp. Clin. Res. 2020, 26, e922012. [CrossRef]

183. Qiu, J.-J.; Lin, X.-J.; Tang, X.-Y.; Zheng, T.-T.; Lin, Y.-Y.; Hua, K.-Q. Exosomal Metastasis-Associated Lung Adenocarcinoma Transcript 1 Promotes Angiogenesis and Predicts Poor Prognosis in Epithelial Ovarian Cancer. Int. J. Biol. Sci. 2018, 14, 1960-1973. [CrossRef]

184. Zhou, Y.; Xu, X.; Lv, H.; Wen, Q.; Li, J.; Tan, L.; Li, J.; Sheng, X. The Long Noncoding RNA MALAT-1 Is Highly Expressed in Ovarian Cancer and Induces Cell Growth and Migration. PLoS ONE 2016, 11, e0155250. [CrossRef] [PubMed]

185. Pa, M.; Naizaer, G.; Seyiti, A.; Kuerbang, G. Long Noncoding RNA MALAT1 Functions as a Sponge of MiR-200c in Ovarian Cancer. Oncol. Res. 2017. [CrossRef] [PubMed]

186. Buttarelli, M.; De Donato, M.; Raspaglio, G.; Babini, G.; Ciucci, A.; Martinelli, E.; Baccaro, P.; Pasciuto, T.; Fagotti, A.; Scambia, G.; et al. Clinical Value of LncRNA MEG3 in High-Grade Serous Ovarian Cancer. Cancers 2020, 12, 966. [CrossRef] [PubMed]

187. Liu, Y.; Xu, Y.; Ding, L.; Yu, L.; Zhang, B.; Wei, D. LncRNA MEG3 Suppressed the Progression of Ovarian Cancer via Sponging MiR-30e-3p and Regulating LAMA4 Expression. Cancer Cell Int. 2020, 20, 181. [CrossRef]

188. Wang, J.; Xu, W.; He, Y.; Xia, Q.; Liu, S. LncRNA MEG3 Impacts Proliferation, Invasion, and Migration of Ovarian Cancer Cells through Regulating PTEN. Inflamm. Res. Off. J. Eur. Histamine Res. Soc. Al 2018, 67, 927-936. [CrossRef]

189. Tao, P.; Yang, B.; Zhang, H.; Sun, L.; Wang, Y.; Zheng, W. The Overexpression of LncRNA MEG3 Inhibits Cell Viability and Invasion and Promotes Apoptosis in Ovarian Cancer by Sponging MiR-205-5p. 11. Int. J. Clin. Exp. Pathol. 2020, 13, 869-879. [PubMed]

190. Fan, Y.; Wang, L.; Han, X.-C.; Ma, H.-Y.; Zhang, N.; Zhe, L. LncRNA MIF-AS1 Aggravates the Progression of Ovarian Cancer by Sponging MiRNA-31-5p. Eur. Rev. Med. Pharmacol. Sci. 2020, 24, 2248-2255. [CrossRef] 
191. Zhu, L.; Wang, A.; Gao, M.; Duan, X.; Li, Z. LncRNA MIR4435-2HG Triggers Ovarian Cancer Progression by Regulating MiR-128-3p/CKD14 Axis. Cancer Cell Int. 2020, 20, 145. [CrossRef]

192. Hu, J.; Wang, L.; Zhao, W.; Huang, Y.; Wang, Z.; Shen, H. Mi-R4435-2HG Promotes Proliferation and Inhibits Apoptosis of Cancer Cells in Ovarian Carcinoma by Upregulating ROCK2. Oncol. Lett. 2020, 19, 1305-1309. [CrossRef]

193. Zhang, L.; Yang, S.; Wang, Y.; Fang, Q.; Chen, X.; Lu, H.; Zhao, L. Long Noncoding RNA MIR4697HG Promotes Cell Growth and Metastasis in Human Ovarian Cancer. Anal. Cell. Pathol. Amst. 2017, 2017, 8267863. [CrossRef]

194. Liu, Y.; Wang, Y.; Fu, X.; Lu, Z. Long Non-Coding RNA NEAT1 Promoted Ovarian Cancer Cells' Metastasis through Regulation of MiR-382-3p/ROCK1 Axial. Cancer Sci. 2018, 109, 2188-2198. [CrossRef]

195. Lin, X.; Tang, X.; Zheng, T.; Qiu, J.; Hua, K. Long Non-Coding RNA NONHSAT076754 Promotes Invasion and Metastasis in Epithelial Ovarian Cancer. J. Cancer 2019, 10, 1930-1940. [CrossRef]

196. Liu, Y.; Zong, Z.-H.; Guan, X.; Wang, L.; Zhao, Y. The Role of Long Non-Coding RNA PCA3 in Epithelial Ovarian Carcinoma Tumorigenesis and Progression. Gene 2017, 633, 42-47. [CrossRef] [PubMed]

197. Min, F.; Chu, G. Long Noncoding RNA PCAT-1 Knockdown Prevents the Development of Ovarian Cancer Cells via MicroRNA124-3p. J. Cell. Biochem. 2020, 121, 1963-1972. [CrossRef] [PubMed]

198. Chen, S.; Wang, L.-L.; Sun, K.-X.; Liu, Y.; Guan, X.; Zong, Z.-H.; Zhao, Y. LncRNA PCGEM1 Induces Ovarian Carcinoma Tumorigenesis and Progression Through RhoA Pathway. Cell. Physiol. Biochem. 2018, 47, 1578-1588. [CrossRef] [PubMed]

199. Chen, Y.; Du, H.; Bao, L.; Liu, W. LncRNA PVT1 Promotes Ovarian Cancer Progression by Silencing MiR-214. Cancer Biol. Med. 2018, 15, 238-250. [CrossRef] [PubMed]

200. Yang, Q.; Yu, Y.; Sun, Z.; Pan, Y. Long Non-Coding RNA PVT1 Promotes Cell Proliferation and Invasion through Regulating MiR-133a in Ovarian Cancer. Biomed. Pharmacother. 2018, 106, 61-67. [CrossRef]

201. Wang, J.; Ding, W.; Xu, Y.; Tao, E.; Mo, M.; Xu, W.; Cai, X.; Chen, X.; Yuan, J.; Wu, X. Long Non-Coding RNA RHPN1-AS1 Promotes Tumorigenesis and Metastasis of Ovarian Cancer by Acting as a CeRNA against MiR-596 and Upregulating LETM1. Aging 2020, 12, 4558-4572. [CrossRef]

202. Zhao, L.; Liu, T.; Zhang, X.; Zuo, D.; Liu, C. LncRNA RHPN1-AS1 Promotes Ovarian Cancer Growth and Invasiveness Through Inhibiting MiR-1299. OncoTargets Ther. 2020, 13, 5337-5344. [CrossRef]

203. Ge, J.; Wu, X.-M.; Yang, X.-T.; Gao, J.-M.; Wang, F.; Ye, K.-F. Role of Long Non-Coding RNA SNHG1 in Occurrence and Progression of Ovarian Carcinoma. Eur. Rev. Med. Pharmacol. Sci. 2018, 22, 329-335. [CrossRef]

204. Hong, L.; Chen, W.; Wu, D.; Wang, Y. Upregulation of SNHG3 Expression Associated with Poor Prognosis and Enhances Malignant Progression of Ovarian Cancer. Cancer Biomark. Sect. Dis. Markers 2018, 22, 367-374. [CrossRef]

205. Yang, X.-S.; Wang, G.-X.; Luo, L. Long Non-Coding RNA SNHG16 Promotes Cell Growth and Metastasis in Ovarian Cancer. Eur. Rev. Med. Pharmacol. Sci. 2018, 22, 616-622. [CrossRef] [PubMed]

206. Guo, Q.; Wang, L.; Zhu, L.; Lu, X.; Song, Y.; Sun, J.; Wu, Z.; Shi, J.; Wang, Z.; Zhou, X. The Clinical Significance and Biological Function of LncRNA SOCAR in Serous Ovarian Carcinoma. Gene 2019, 713, 143969. [CrossRef] [PubMed]

207. Yu, J.; Han, Q.; Cui, Y. Decreased Long Non-Coding RNA SPRY4-IT1 Contributes to Ovarian Cancer Cell Metastasis Partly via Affecting Epithelial-Mesenchymal Transition. Tumor Biol. 2017, 39, 1010428317709129. [CrossRef] [PubMed]

208. Qiu, J.-J.; Lin, X.-J.; Tang, X.-Y.; Zheng, T.-T.; Zhang, X.-Y.; Hua, K.-Q. Long Noncoding RNA TC0101441 Induces EpithelialMesenchymal Transition in Epithelial Ovarian Cancer Metastasis by Downregulating KiSS1. Int. J. Cancer 2020, 146, $2588-2598$. [CrossRef]

209. Chen, S.; Wang, L.-L.; Sun, K.-X.; Xiu, Y.-L.; Zong, Z.-H.; Chen, X.; Zhao, Y. The Role of the Long Non-Coding RNA TDRG1 in Epithelial Ovarian Carcinoma Tumorigenesis and Progression through MiR-93/RhoC Pathway. Mol. Carcinog. 2018, 57, 225-234. [CrossRef]

210. Ge, J.; Han, T.; Shan, L.; Na, J.; Li, Y.; Wang, J. Long Non-Coding RNA THOR Promotes Ovarian Cancer Cells Progression via IL-6/STAT3 Pathway. J. Ovarian Res. 2020, 13, 72. [CrossRef]

211. Xu, Q.; Lin, Y.-B.; Li, L.; Liu, J. LncRNA TLR8-AS1 Promotes Metastasis and Chemoresistance of Ovarian Cancer through Enhancing TLR8 MRNA Stability. Biochem. Biophys. Res. Commun. 2020, 526, 857-864. [CrossRef]

212. Liu, Y.; Li, L.; Wang, X.; Wang, P.; Wang, Z. LncRNA TONSL-AS1 Regulates MiR-490-3p/CDK1 to Affect Ovarian Epithelial Carcinoma Cell Proliferation. J. Ovarian Res. 2020, 13, 60. [CrossRef]

213. Wu, W.; Gao, H.; Li, X.; Zhu, Y.; Peng, S.; Yu, J.; Zhan, G.; Wang, J.; Liu, N.; Guo, X. LncRNA TPT1-AS1 Promotes Tumorigenesis and Metastasis in Epithelial Ovarian Cancer by Inducing TPT1 Expression. Cancer Sci. 2019, 110, 1587-1598. [CrossRef]

214. Liu, X.; Li, Y.; Wen, J.; Qi, T.; Wang, Y. Long Non-Coding RNA TTN-AS1 Promotes Tumorigenesis of Ovarian Cancer through Modulating the MiR-139-5p/ROCK2 Axis. Biomed. Pharmacother. 2020, 125, 109882. [CrossRef]

215. Miao, S.; Wang, J.; Xuan, L.; Liu, X. LncRNA TTN-AS1 Acts as Sponge for MiR-15b-5p to Regulate FBXW7 Expression in Ovarian Cancer. BioFactors 2020, 46, 600-607. [CrossRef] [PubMed]

216. Kuang, D.; Zhang, X.; Hua, S.; Dong, W.; Li, Z. Long Non-Coding RNA TUG1 Regulates Ovarian Cancer Proliferation and Metastasis via Affecting Epithelial-Mesenchymal Transition. Exp. Mol. Pathol. 2016, 101, 267-273. [CrossRef] [PubMed]

217. Yang, X.; Xin, N.; Qu, H.-J.; Wei, L.; Han, Z. Long Noncoding RNA TUG1 Facilitates Cell Ovarian Cancer Progression through Targeting MiR-29b-3p/MDM2 Axis. Anat. Rec. 2020, 303, 3024-3034. [CrossRef] [PubMed]

218. Wang, H.; Su, H.; Tan, Y. UNC5B-AS1 Promoted Ovarian Cancer Progression by Regulating the H3K27me on NDRG2 via EZH2. Cell Biol. Int. 2020, 44, 1028-1036. [CrossRef] 
219. Li, W.; Ma, S.; Bai, X.; Pan, W.; Ai, L.; Tan, W. Long Noncoding RNA WDFY3-AS2 Suppresses Tumor Progression by Acting as a Competing Endogenous RNA of MicroRNA-18a in Ovarian Cancer. J. Cell. Physiol. 2020, 235, 1141-1154. [CrossRef] [PubMed]

220. Zuo, K.; Zhao, Y.; Zheng, Y.; Chen, D.; Liu, X.; Du, S.; Liu, Q. Long Non-Coding RNA XIST Promotes Malignant Behavior of Epithelial Ovarian Cancer. OncoTargets Ther. 2019, 12, 7261-7267. [CrossRef]

221. Kulis, M.; Esteller, M. 2-DNA Methylation and Cancer. In Advances in Genetics; Herceg, Z., Ushijima, T., Eds.; Epigenetics and Cancer, Part A; Academic Press: Cambridge, MA, USA, 2010; Volume 70, pp. 27-56.

222. Pfeifer, G.P. Defining Driver DNA Methylation Changes in Human Cancer. Int. J. Mol. Sci. 2018, 19, 1166. [CrossRef]

223. Wang, S.; Wu, W.; Claret, F.X. Mutual Regulation of MicroRNAs and DNA Methylation in Human Cancers. Epigenetics 2017, 12, 187-197. [CrossRef]

224. Glaich, O.; Parikh, S.; Bell, R.E.; Mekahel, K.; Donyo, M.; Leader, Y.; Shayevitch, R.; Sheinboim, D.; Yannai, S.; Hollander, D.; et al. DNA Methylation Directs MicroRNA Biogenesis in Mammalian Cells. Nat. Commun. 2019, 10, 5657. [CrossRef]

225. Chen, K.; Liu, M.X.; Mak, C.S.-L.; Yung, M.M.-H.; Leung, T.H.-Y.; Xu, D.; Ngu, S.-F.; Chan, K.K.-L.; Yang, H.; Ngan, H.Y.-S.; et al. Methylation-Associated Silencing of MiR-193a-3p Promotes Ovarian Cancer Aggressiveness by Targeting GRB7 and MAPK/ERK Pathways. Theranostics 2018, 8, 423-436. [CrossRef]

226. Loginov, V.I.; Pronina, I.V.; Burdennyy, A.M.; Filippova, E.A.; Kazubskaya, T.P.; Kushlinsky, D.N.; Utkin, D.O.; Khodyrev, D.S.; Kushlinskii, N.E.; Dmitriev, A.A.; et al. Novel MiRNA Genes Deregulated by Aberrant Methylation in Ovarian Carcinoma Are Involved in Metastasis. Gene 2018, 662, 28-36. [CrossRef]

227. Deng, Y.; Zhao, F.; Hui, L.; Li, X.; Zhang, D.; Lin, W.; Chen, Z.; Ning, Y. Suppressing MiR-199a-3p by Promoter Methylation Contributes to Tumor Aggressiveness and Cisplatin Resistance of Ovarian Cancer through Promoting DDR1 Expression. J. Ovarian Res. 2017, 10, 50. [CrossRef]

228. Braga, E.A.; Loginov, V.I.; Burdennyi, A.M.; Filippova, E.A.; Pronina, I.V.; Kurevlev, S.V.; Kazubskaya, T.P.; Kushlinskii, D.N.; Utkin, D.O.; Ermilova, V.D.; et al. Five Hypermethylated MicroRNA Genes as Potential Markers of Ovarian Cancer. Bull. Exp. Biol. Med. 2018, 164, 351-355. [CrossRef] [PubMed]

229. Ye, Z.; Li, J.; Han, X.; Hou, H.; Chen, H.; Zheng, X.; Lu, J.; Wang, L.; Chen, W.; Li, X.; et al. TET3 Inhibits TGF-B1-Induced Epithelial-Mesenchymal Transition by Demethylating MiR-30d Precursor Gene in Ovarian Cancer Cells. J. Exp. Clin. Cancer Res. 2016, 35, 72. [CrossRef]

230. Teng, Y.; Zuo, X.; Hou, M.; Zhang, Y.; Li, C.; Luo, W.; Li, X. A Double-Negative Feedback Interaction between MicroRNA-29b and DNMT3A/3B Contributes to Ovarian Cancer Progression. Cell. Physiol. Biochem. 2016, 39, 2341-2352. [CrossRef] [PubMed]

231. Li, T.; Li, Y.; Gan, Y.; Tian, R.; Wu, Q.; Shu, G.; Yin, G. Methylation-Mediated Repression of MiR-424/503 Cluster Promotes Proliferation and Migration of Ovarian Cancer Cells through Targeting the Hub Gene KIF23. Cell Cycle 2019, 18, 1601-1618. [CrossRef] [PubMed]

232. Lu, L.; Katsaros, D.; de la Longrais, I.A.R.; Sochirca, O.; Yu, H. Hypermethylation of Let-7a-3 in Epithelial Ovarian Cancer Is Associated with Low Insulin-like Growth Factor-II Expression and Favorable Prognosis. Cancer Res. 2007, 67, 10117-10122. [CrossRef] [PubMed]

233. Iorio, M.V.; Visone, R.; Leva, G.D.; Donati, V.; Petrocca, F.; Casalini, P.; Taccioli, C.; Volinia, S.; Liu, C.-G.; Alder, H.; et al. MicroRNA Signatures in Human Ovarian Cancer. Cancer Res. 2007, 67, 8699-8707. [CrossRef]

234. Lujambio, A.; Calin, G.A.; Villanueva, A.; Ropero, S.; Sánchez-Céspedes, M.; Blanco, D.; Montuenga, L.M.; Rossi, S.; Nicoloso, M.S.; Faller, W.J.; et al. A MicroRNA DNA Methylation Signature for Human Cancer Metastasis. Proc. Natl. Acad. Sci. USA 2008, 105, 13556-13561. [CrossRef]

235. Özeş, A.R.; Miller, D.F.; Özeş, O.N.; Fang, F.; Liu, Y.; Matei, D.; Huang, T.; Nephew, K.P. NF-KB-HOTAIR Axis Links DNA Damage Response, Chemoresistance and Cellular Senescence in Ovarian Cancer. Oncogene 2016, 35, 5350-5361. [CrossRef] [PubMed]

236. Teschendorff, A.; Lee, S.-H.; Jones, A.; Fiegl, H.; Kalwa, M.; Wagner, W.; Chindera, K.; Evans, I.; Dubeau, L.; Orjalo, A.; et al. HOTAIR and Its Surrogate DNA Methylation Signature Indicate Carboplatin Resistance in Ovarian Cancer. Genome Med. 2015, 7, 108. [CrossRef] [PubMed]

237. Zhou, J.; Yang, L.; Zhong, T.; Mueller, M.; Men, Y.; Zhang, N.; Xie, J.; Giang, K.; Chung, H.; Sun, X.; et al. H19 LncRNA Alters DNA Methylation Genome Wide by Regulating S-Adenosylhomocysteine Hydrolase. Nat. Commun. 2015, 6, 10221. [CrossRef]

238. Gloss, B.S.; Patterson, K.I.; Barton, C.A.; Gonzalez, M.; Scurry, J.P.; Hacker, N.F.; Sutherland, R.L.; O’Brien, P.M.; Clark, S.J. Integrative Genome-Wide Expression and Promoter DNA Methylation Profiling Identifies a Potential Novel Panel of Ovarian Cancer Epigenetic Biomarkers. Cancer Lett. 2012, 318, 76-85. [CrossRef] [PubMed]

239. Gloss, B.; Moran-Jones, K.; Lin, V.; Gonzalez, M.; Scurry, J.; Hacker, N.F.; Sutherland, R.L.; Clark, S.J.; Samimi, G. ZNF300P1 Encodes a LincRNA That Regulates Cell Polarity and Is Epigenetically Silenced in Type II Epithelial Ovarian Cancer. Mol. Cancer 2014, 13, 3. [CrossRef] [PubMed]

240. Vrba, L.; Futscher, B.W. Epigenetic Silencing of LncRNA MORT in 16 TCGA Cancer Types. F1000Research 2018, 7, 211. [CrossRef]

241. Vera, O.; Rodriguez-Antolin, C.; de Castro, J.; Karreth, F.A.; Sellers, T.A.; Caceres, I.I. de An Epigenomic Approach to Identifying Differential Overlapping and Cis-Acting LncRNAs in Cisplatin-Resistant Cancer Cells. Epigenetics 2018, 13, 251-263. [CrossRef]

242. Pilié, P.G.; Gay, C.M.; Byers, L.A.; O'Connor, M.J.; Yap, T.A. PARP Inhibitors: Extending Benefit Beyond BRCA-Mutant Cancers. Clin. Cancer Res. 2019, 25, 3759-3771. [CrossRef]

243. A Multi-Omics Study on the Invasiveness of Epithelial Ovarian Cancer. Available online: https://clinicaltrials.gov/ct2/show/ NCT03742856 (accessed on 4 August 2020). 